\title{
Şeyl Gazı; Jeolojik Özellikleri, Çevresel Etkileri ve Küresel Ekonomik Anlamı
}

\author{
Shale Gas; Geological Properties, Environmental Effects and Global Economic Meaning
}

\author{
Nazan YALÇIN ERIKK \\ Cumhuriyet Üniversitesi, Mühendislik Fakültesi Jeoloji Mühendisliği Bölümü, 58140, SİVAS \\ nyalcin@cumhuriyet.edu.tr
}

\section{ÖZ}

Küresel enerji prospeksiyonu özellikle son birkaç yıl içinde üretilmesi güç petrol (tight reservoir) ve şeyl gaz (kaya gazı) gibi geleneksel olmayan enerji kaynaklarının (ankonvansiyonel) üretiminde kullanılabilecek teknolojinin gelişmesi ile önemli oranda değişim göstermiştir. Ekonomik olarak büyük katkı sağladığı görülen ve gelecekte ekonomik, sosyal ve politik alanlarda daha büyük etki potansiyelinin olacağı öngörülen bu kaynaklar, birçok ülkede ve milyonlarca insan tarafindan yüzey suları, yeraltı suları ve yerel hava kalitesi açısından zararlı olduğu gerekçesi ile protesto edilmiş ve bu konuların da ekonomik getiri ile birlikte ayrıntılı olarak değerlendirilmesini zorunlu kılmıştır. Özellikle, küresel ölçekte yaşanan doğal felaketler, 20. yüzyılda küresel ısınma, atmosferin kimyasal bileşimi ve bu bileşimsel değişikliklerin ekoloji ve insanlığa olan etkisine ilgi çekmiştir. Bu makalede özellikle son yılların ilgi odağı haline gelen, ekonomik prospeksiyonları alt üst etmesi yanı sıra, küresel politikanın da belki yeniden şekillenmesine neden olan şeyl gazının oluşumu, şeyl kaynak kayalarının petrofiziksel özellikleri, araştırma ve üretim teknikleri ile ülkelerin enerji ihtiyacının karşılanmasındaki rolü, bu sırada ekolojiye olan etkileri değerlendirilmiştir. Enerji kaynaklarının tarihsel süreçte olduğu gibi gelecekte de sadece yakıt ve enerji kaynağ1 olarak bir anlam taşımayacağı, ekonomi ve sosyal alanlardaki etkilerinden bahsedilerek ifade edilmeye çalışılmıştır.

Anahtar Kelimeler: Emisyonlar, enerji kaynakları, hidrolik çatlatma, küresel 1sınma, şeyl gaz

\section{ABSTRACT}

Global energy prospecting has significantly shown change with the development of technology that can be used in the production of energy sources which are unconventional such as tight reservoir and shale gas especially within last several years. These sources which are economically seen as a great contribution and are predicted that it will be greater impact potential in the fields of economic, social and politics in the future have been protested on the ground water, surface water and local air quality by millions of people in many countries because of harmful and it has necessitated that these subjects are evaluated in details with the economic benefits. Especially, natural disasters which have been encountered at global 
scale have drawn attention to the effect of the chemical composition of the atmosphere and compositional changes on humanity and echology in the 20th century. In this article, as well as it has been turn under economic prospecting, the formation of shale gas which becomes focus of interest especially of the last few years and also maybe causes to the configuration of global politics again, petrophysical features of shale source rock, the role on the fulfillment of the energy need of the countries with searching and production techniques; and meanwhile the effects on ecology have been evaluated. It has been tried to be stated that energy sources will not have a meaning as only fuel and energy source in the future just like in the historical process by being mentioned about their effects on the fields of economy and social.

Key Words: Emissions, energy sources, global warming, hydraulic fracturing, shale gas

\section{GÍRISŞ}

Petrol ve türevleri insanlık tarihiyle neredeyse yaşıttır ve öncelikle toplumların sosyal hayatlarına, ardından da ekonomilerine hizla girmeleri sonucunda edindikleri "vazgeçilemez enerji kaynağı" özelliğini korumaktadırlar. Dünyada varlığı milattan önceki yıllarda bile bilinip, çeşitli şekillerde kullanılsa da petrolün ekonomik üretimine başlandığ 1 1850' li yıllarda "Çağın Işı ğı” olarak adlandırılmış (Yergin, 1991), "Fosil Enerji Kaynakları", "Tükenebilir Enerji Kaynakları" ve günümüzde de "geleneksel enerji kaynağ 1 (konvansiyonel)" olarak tanımlanmıştır. Petrol ve doğal gaz gibi kaynakların dünyadaki nüfus artışından da hızla artan enerji ihtiyacına yeterince karşılık gelmemesi nedeniyle farklı ve yeni enerji kaynaklarına olan ilgi artmış, sonuçta geleneksel olmayan (ankonvansiyonel) enerji kaynakları olarak tanımlanan şeyl gazı/kaya gazı (shale gas), bitümlü şeyl (oil shale), kömür kökenli gaz (Coal Bed Methane; CBM) ve üretilmesi güç gaz ve petrol (oil and gas in tight reservoirs), gas hidratlar (methane hidrates), ağır-petrollü kumtaşları (tar sands) değerlendirilmeye başlanmıştır. Bu konuda, özellikle dünyada petrol fiyatlarının dalgalı seyri ve yükseliş veya düşüşlerinde yaşanan şiddetli global etkiler, sadece ekonomik olmaktan oldukça uzaktır ve tüm dünyada yaşanan büyük sosyal ve politik gelişmeleri ve hatta savaşları da beraberinde getirmiştir. Temmuz
2008' de 147.27 USD/Varillik fiyat, petrol fiyat tarihçesinde pik noktası olmuştur. Özellikle fosil enerji kaynağı bakımından fakir ülkeler, petrol ile ilgili bu ekonomik buhran dönemlerinden ez az zararla kurtulabilmek ve enerji ihtiyaçlarını karşılayabilmek için yeni kaynaklara yönelmiştir. $\mathrm{Bu}$ değişim süreci içinde yenilenebilir enerji kaynakları (rüzgar, güneş, dalga enerjisi, hidrolik gibi) da araştırılmış ve hatta birçok ülkede önemli ataklar ve teknolojik gelişimler neticesinde ekonomik olarak anlamlı girdiler sağlanmıştır. Ancak, hiçbir zaman yenilenebilir enerji kaynaklarının petrol ve doğal gaz kadar enerji ihtiyacını karşılayacak potansiyeli ve enerji politikalarında yön değiştirici gücü olmamıştır. Bununla birlikte, özellikle Kuzey Amerika'da y1lların petrolcülük birikimi ve deneyimleri üzerine yapılan etkin çalışmalar neticesinde yeraltında normal üretim süreçleri ile çıkarılamayan ve bu haliyle ekonomik olmayan şeyl gazı, şeyl petrolü, katranlı kumlara yönelim başlamıştır. Elbette, ankonvansiyonel enerji kaynakları uzun yıllardır bilinmektedir, ancak bunlardan hidrokarbonların üretilmesi için önemli oranda rezervuar ve kuyu operasyonlarının uygulanması gerekmektedir. $\mathrm{Bu}$ işlem ise istenmeyen ek bir maliyet anlamı da taşımaktadır. Amerika Birleşik Devletlerinde yatay sondaj ve hidrolik çatlatma gibi yöntemlerin gelişimi ve bunların şeyl gazının üretiminde yaygın olarak kullanılması, küresel ölçekte petrol 
piyasasında arz talep dengelerini değiştiren bir katalizör olmuştur (Artur ve Cole, 2014; Lacatos ve Szabo, 2009; Kavak, 2013). Konvansiyonel gaz rezervuarlarının aksine, ankonvansiyonel gazların üretilmesi için gereken bu zor ve maliyetli işlemler, teknolojik gelişim sayesinde oldukça kolay ve ucuz hale gelip, enerji ve ekonomi piyasaları için dikkat çekici olmaya başlamış ve üretim yönelimini bu tarafa yöneltmiştir (Şekil 1). sıradaki enerji kaynağıdır ve 2035 yılına kadar bu ihtiyacın \%50 oranında artacağ1 öngörülmüştür (Şekil 1). Örneğin, Kuzey Amerika'daki geleneksel olmayan doğal gaz üretiminin oldukça hızlı gelişimi, dünyada yeni bir jeopolitik-politik paradigmanın doğmasını sağlamıştır. Amerika'da geniş şeyl gaz sahalarının keşfedilmesinden sonra yeni yerel pazarlar oluşmuş ve diğer ülkeler için de örnek olacak bir gelişme kaydedilmiştir.

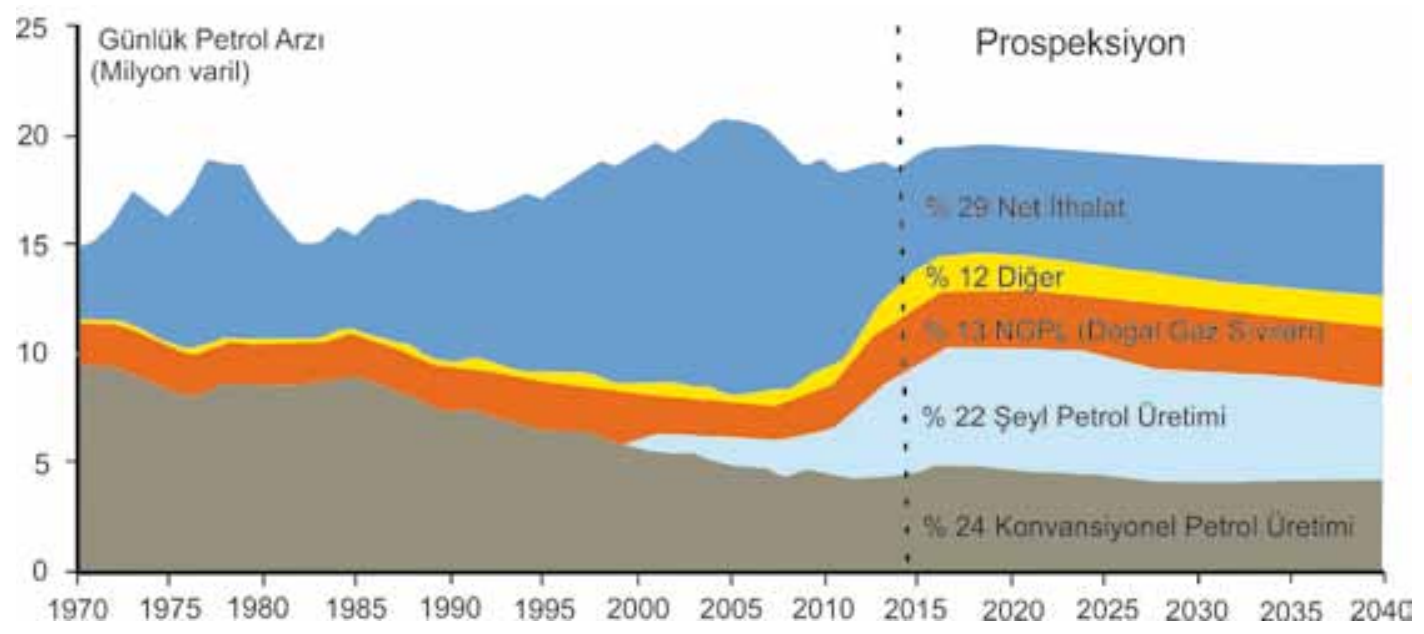

Şekil 1. Amerika Birleşik Devletleri'nde kaynaklara göre ham petrol ve diğer sıvı yakıtlar arzı (1970-2040) (US EIA, 2013(2013 a)

Figure 1. Crude oil and other liquid fuels supply according to sources in the United States (1970-2040) (US EIA, 2013a)

Son 20-25 y1llı süreçte, özellikle hidrokarbon üretim alanında uygulanan yeni teknolojiler sayesinde, küresel enerji perspektifi önemli oranda değişmiştir (CPFI, 2013). US EIA (2013)(2013 a) verilerine göre 41 ülkede, 95 havzada ve 137 formasyonda şeyl gaz üretimi ve araştırma faaliyetleri bulunmaktadır. Ekonomik veya ekonomik olmayan tüm kaynakları kapsayan “Teknik olarak kurtarılabilir” şeyl gaz rezervi (TRR), 2011 yılında 6622 trilyon feet küp (Tcf) iken, 2013 yılında 7299 Tcf' e kadar çıkmıştır. Amerikan Enerji Bilgi Dairesi (US EIA 2013a)'ne göre, dünyadaki enerji ihtiyacının karşılanması bakımından doğal gaz petrolden sonra ikinci
Geleneksel olmayan gaz ve petrol dünyanın diğer ülkeleri içinde ithal edilen gaz ve petrol ihtiyacının azalmasına neden olarak, fiyatlarında önemli düşüşlere, enerji politikaları ve yeni ekonomiksiyaset-politika kurgularının oluşmasına neden olmuştur.

$\mathrm{Bu}$ çalışma ile de öncelikle şeyllerin çökelim ve değişim süreçleri ile bileşimsel özellikleri jeolojik bakış açısı ile değerlendirilerek, şeyllerde oluşan ve üretilen gazların sedimanter havzadaki türüm süreçleri ile araştırma-üretim yöntemleri hakkında bilgi verilecektir. Tüm bu bilgiler 1şığında dünyada ve ülkemizdeki şeyl gaz rezervleri, global ekonomik-sosyal ve ekolojik 
önemleri hakkında yapılan güncel çalışmaların bütünleşik bir şekilde özetlenmesi mümkün olacaktır.

\section{Fosil Enerji Kaynaklarına Genel Bakış}

Fosil enerji kaynakları başlıca petrol, doğal gaz ve bitümlü şeyllerden oluşan, farklı şekillerde değerlendirilmeleri mümkün olan temel enerji kaynağı yakıtlardır. $\mathrm{Bu}$ kaynaklar yüzlerce yıldır dünya enerji piyasasındaki hakimiyetlerini değişen oranlarda da olsa sürdürmektedir. Son yıllarda ise, kökensel olarak konvansiyonel kaynaklar ile aynı, fakat üretim yöntemindeki farklılıklar nedeniyle "ankonvansiyonel enerji kaynakları" olarak tanımlanan şeyl gazı büyük dikkat çekmiş ve çekmeye devam etmektedir. Genel olarak, konvansiyonel petrol ve doğal gaz oluşumu için gerekli etkenler ve süreçlerin oluşturduğu birliktelik "petrol sistemi” olarak tanımlanır ve petrol veya gazın oluşumunu sağlayabilecek bir kaynak kaya, birikimi için hazne kaya ile gözeneksiz ve çatlaksız özelliklere sahip bir örtü seviyesinden oluşur (Tissot ve Welte, 1984; Yalçın, 2013). Kaynak kaya, hazne kaya ve örtü kaya gibi petrol sistemi unsurlar1, hidrokarbonların (petrol, doğal gaz) oluşum, birikim, kapanlanma ve korunumunu sağlayarak verimli bir rezervuar alanının, dolayısıyla bir petrol sisteminin gelişmesine neden olur (Yalçın, 2013). Konvansiyonel hidrokarbonların oluşum ve üretim süreçleri düşünüldüğünde, bir oluşum ve hareket zincirinden bahsedilebilir. Kaynak kayada oluşan petrol ve/veya gazların değişen mesafelerde ve jeolojik zaman süresinde yaptığı hareketler ile (göç/migrasyon) uygun bir hazne kaya buluncaya kadar olan yer değişim süreci ve etkinliği vardır. Uygun bir rezervuarda biriken petrol/gaz, jeolojik, jeofizik ve sondajlı araştırmalar ile bu bilgilerin yorumlanması neticesinde bulunup, üretime alınmaya karar verildiğinde "organik madde" ile başlayan bu milyon y1llık maraton, ekonomiye "para girişis" şeklinde bir bakıma sonlanır. $\mathrm{Bu}$ uzun ve kompleks jeolojik süreçler ile üretilen kaynaklar "Konvansiyonel gaz ve petrol" olarak tanımlanır.

Ankonvansiyonel hidrokarbon kaynak kaynakları ise tipik olarak ince taneli, koyu grisiyah renkli, organik maddece zengin olup, petrol/ doğal gaz için aynı zamanda rezervuar ve örtü kaya özelliği de sunmaktadır (Tissot ve Welte, 1984). Bu tip bir rezervuar, konvansiyonel olanlar kadar gözenekli olsa bile bunların aşırı küçük gözenek boşluk boyutları ve permeabilitelerinin neredeyse olmayışı, rezervuardaki akışkanın viskozitesi, hidrokarbonların hareketliliği dolayısıyla da üretim potansiyeli ve verimliliğini birincil olarak etkileyen faktörlerdir (Passey vd., 2010). Şeyl kaynak kayalarının bu petrofiziksel özellikleri nedeniyle hidrokarbonlar, doğal veya yapay unsurlarla çatlaklar oluşturulmadan serbestleşemez ve kaynak kayadan dışarı çıkamazlar (Ratner ve Tiemann, 2013).

Çok basit bir tanımlama ile şeyl gazı (kaya gazı) ince taneli, organik maddece (kerojen) zengin, tabakalı, yapraklanma özellikli sedimanter kayaçlardan türeyen gazdır ve "geleneksel olmayan, ankonvansiyonel” gaz kaynağı olarak ifade edilir ki, geleneksel gaz kaynaklarının “konvansiyonel” üretimi, kumtaşları gibi porozite ve permeabilitesi uygun gazların rahatlikla hareket edebilecekleri özelliklerdeki kayaçlardan yapılır. Bilinen gaz yataklarından doğal gaz üretiminden daha farklı bir yöntem kullanılarak gaz üretilmesi nedeniyle de şeyl kayaçlarından ve kömür yataklarından elde edilen gaza "konvansiyonel olmayan gaz" olarak adlandırılmaktadır. Şeyl gazı, geleneksel doğal gazlardan farklı olmayıp, aynı bileşim özelliğine sahiptir, geleneksel doğal gazlarda olduğu gibi metan, etan ve propan gibi hidrokarbon gazlarının karışımı söz konusu 
ise de, çoğunlukla metan egemen (>\%90) konuşulmaya başlansa, hep "eğer biterse" ile bileşendir. Konvansiyonel doğal gazlar ile benzer şekilde pazarlanır ve satışa sunulur (Staff, 2010). Geleneksel ve geleneksel olmayan gazlar arasındaki ilişki Şekil 2' de verilmiştir. başlayan soruların karşısında "peki o zaman" sorusu yanıt olarak gelmiştir. Bu nedenle, öncelikle yenilenebilir enerji kaynakları olarak tanımlanan (rüzgar, güneş vb.) enerji kaynakları araştırılıp

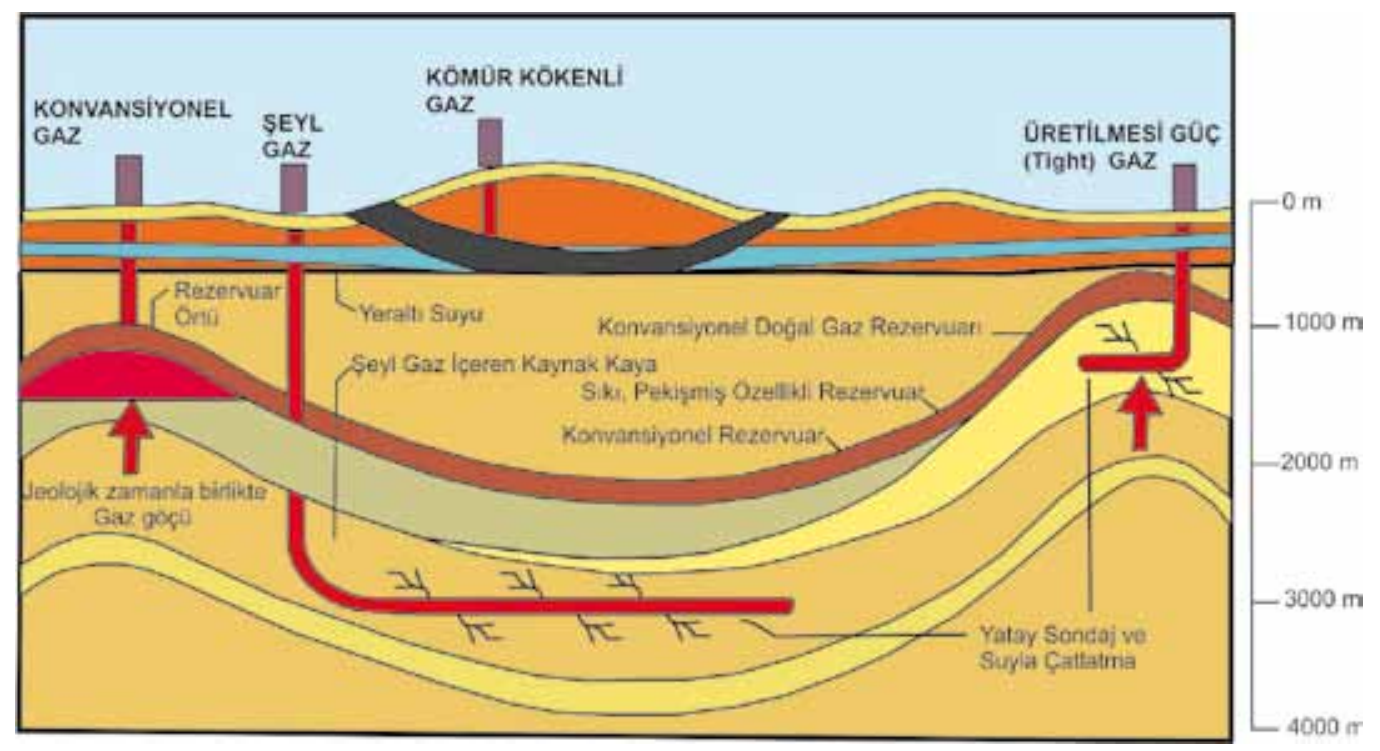

Şekil 2. Konvansiyonel ve konvansiyonel olmayan gazlar arasındaki ilişki (US EIA, 2010)

Figure 2. The relationship between conventional and non-conventional gases (US EIA, 2010)

\subsection{Neden Şeyl Gazı?}

Tüm dünyada petrol ve doğal gazın tükenebilir enerji kaynakları olarak tanımlanması ve potansiyel kullanım zamanına ilişkin tahminler birçok pozitif ve negatif senaryonun gelişimine olanak sağlamıştır. $\mathrm{Bu}$ öngörülerden büyük kısmı geçmişte yaşanan olayları dikkate almış, politika- ekonomi- siyaset "PES" üçgeninde özellikle petrol olmak üzere konvansiyonel enerji kaynakları etkisi birçok kez göstermiştir (Şekil 3). Geçmiş deneyimlerin de birçok kez kanıtladığı gibi, petrol hiçbir zaman sadece masum bir yakıt, bir hammadde ve enerji kaynağı olmamıştır.

Petrol ve doğal gaz ile ilgili konular akademik ve sosyal çevrelerde ne zaman günlük hayata adapte edilmeye çalışılmış, ancak sürekliliğinin ve depolamanın sorun olması nedeniyle petrol ve gaza alternatiflikten ziyade çoğu zaman bu kaynaklara destek rolünde kalmıştır. Yeni kaynak arayışları ise önceden ekonomik olarak değerlendirilmeyen ve belki de ihtiyaç duyulmayan kaynakların tekrar gündeme alınması şeklinde gelişmiştir. Bu konuda Kuzey Amerika'da katranlı kumlardan (tar sands) itibaren üretim ve şeyl gazı "kaya gazı" olarak tarif edilen s1k1 (porozitesi çok az veya hiç olmayan, iyi pekişmiş) formasyonlardan yararlanmanın yolları aranmaya başlanmıştır. $\mathrm{Bu}$ gelişmeler elbette üretim ve aramacılıkta teknoloji ve bilgi birikiminin artması ile baş döndürücü hızlı ekonomik bir sürecin gelişimine neden olmuştur. 


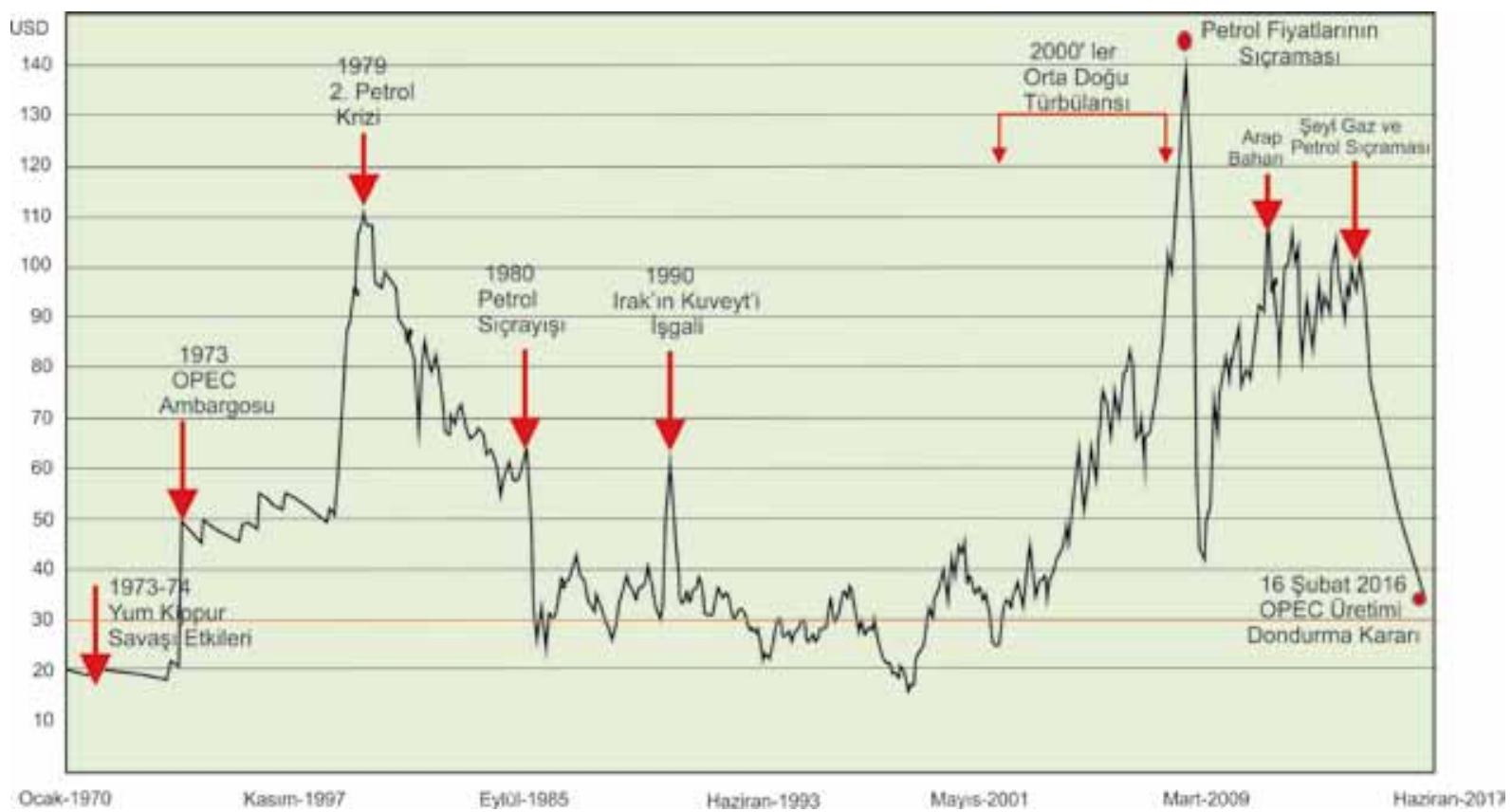

Şekil 3. Petrolün (WTI petrolü) tarihsel süreç içinde değişen fiyat1, ilgili küresel olaylar ve etkiler (www.ktwop. com)

Figure 3. Oil (WTI oil) prices, related changes in the historical process and the impact of global events (www. ktwop.com)

Şeyl gaz potansiyeli olan formasyonların dünyada petrole göre daha cömert ve adil dağılımı, bir bakıma konvansiyonel fosil yakıtlara olan bağımlılı̆̆ azaltması, ekonomik anlamı kadar yeni iş olanaklarının da yaratılmasını sağlamıştır. Tüm bu özellikleri bile şeyl gazının sosyo-ekonomik önemini vurgulamak için aslında yeterlidir. Örneğin, Amerika'nın 2010 yılında toplam doğalgaz üretiminin yüzde 23' ü şeyl gazından sağlanmıştır. US EIA'nın (U.S. Energy Information Administration) 2012 y1lı raporunda Amerika'nın 2020 yılında toplam doğalgaz üretiminin yarısının, 2035 yılında ise yüzde 46' sını şeyl gazından elde edileceği öngörülmektedir. Sadece ABD'nin Teksas eyaletinde bu amaçla yapılan çalışmalarda 12.000 kişiye istihdam sağlanmıştır. Petrol fiyatları 2008 yılında varil başına 147,7 dolara yükseldiğinde, Amerika Birleşik Devletleri'nin petrol ve doğal gaz üretiminin uzun vadede bir düşüşe geçeceği, enerji arz güvenliği açısından, ithal petrol ve doğal gaza olan bağımlılığının artacağı tahmin edilmişti. Ancak bu tahmin, konvansiyonel olmayan petrol ve doğal gaz alanında devrim niteliğindeki gelişmeler sayesinde tamamen farklı bir yol izlemiştir (World Energy Outlook 2015).

Yatay sondaj (horizontal drilling) ve hidrolik çatlatma (hydraulic fracking, hydrofracturing) tekniklerinin gelişmesi ile, Amerika'nın ürettiği doğal gaz miktarı 2010 yılından bu yana yaklaşık yüzde 25 oranında artmıştır. $\mathrm{Bu}$ artış, ABD’nin Rusya’yı geride bırakarak dünyanın en büyük doğal gaz üreticisi konumuna gelmesini sağlamıştır. Şeyl petrolü üretimindeki bu olağanüstü artışla birlikte ithalatını büyük oranda düşüren ABD'nin diğer büyük petrol üreticilerine olan bağımlılı̆ğ da azalmıştır. 2005'te yüzde 60 seviyesinde olan Amerika'nın net ithalatıyla karşıladığı akaryakıt 
tüketim oranı böylece 2013 yılında yüzde 33'e düşmüştür. $\mathrm{Bu}$ oranın daha da düşerek yüzde 22'ye, yani 1970 yllından bu yana görülen en düşük seviyeye gerileyeceği öngörülmektedir (World Energy Outlook 2015).

Büyümeye ve çeşitlenmeye devam eden küresel enerji arzı, Amerika'nın şeyl gazı ve şeyl petrolüne dayalı yeni enerji stratejisinin etkisiyle dönüşüme uğramaya başlamıştır. Ancak ABD’nin petrol üretimindeki bu artışa ve Amerika'daki şeyl gazı ve şeyl petrolü üretiminin Irak' ın üretiminden daha yüksek olduğu bilinmesine rağmen, piyasa fiyatlarında uzun zamandır düşüş gözlemlenmiştir. ABD'nin enerji arzında yakaladığı büyümenin petrol fiyatlarını düşürmesi öngörülmüş, bu beklenti de gerçekleşmiştir (16.02.2016 Petrol Varil Fiyatı 33 USD) (World Energy Outlook 2015).

\section{JEOLOJİK BAKIŞ AÇISI İLE ŞEYLLER VE ŞEYL GAZI TÜRÜM SÜRECI}

Şeyl; Şeyl ve siltler yerkabuğundaki en yaygın sedimanter kayaçlardandır. Petrol jeolojisinde organik maddece zengin şeyller kaynak kaya özelliği ile olduğu kadar petrol ve gazın birikimi ve kapanlanmasını sağlayacak örtü ve rezervuar oluşumunu da sağlayabilirler (Tissot ve Welte, 1984). Rezervuar mühendisliğinde şeyller, sıv1 akışını engelleyen bariyerler olarak tanımlanır. Sismik araştırmalarda ise şeyl düzeyleri, takibi kolay olan birimler olup, sismik ve petrofiziksel özellikleri de dahil olmak üzere tüm petrol araştırma ve rezervuar değerlendirmelerinde pozitif ve negatif yönde büyük öneme sahiptir.

Kayaç oluşumları bakımından şeyller, tipik olarak ince tanelerden, çoğunlukla da killer (illit, klorit ve smektir gibi) ve kuvars, feldispat ve çört ile diğer ağır minerallerden oluşur ve yaprağımsı, laminalı özelliklere sahiptir.
Genellikle göl ve denizlerin diplerinde, enerjinin düşük olduğu çökelim şartlarında birikirler. Günümüzde gaz üretimi yapılan şeyl rezervuarları çoğunlukla olgun-aşırı olgun, organik maddece zengin kaynak kayalardır (Bryndzia ve Braunsdorf, 2014). Dokusal ve yapisal olarak değerlendirildiğinde de şeyller, kil ve silt boyu taneleri ile kırıntılı/detritik kayaçlardır. Önemli oranda organik madde sediman çökelimine eşlik ettiğinde ise şeyller organik maddece zengin olmaya başlar ve ilerleyen jeolojik zamanlarda havza bazında gerekli basınç ve sıcaklık şartlarını yakaladığında kaynak kaya olma potansiyeline sahip olabilir.

Şeyl kaynak kayaları, mm den daha büyük ölçeklerde bile oldukça etkin dokusal ve bileşimsel hetorejenlik sunarlar. Şeyl gazı üretilen sahalardaki verimli seviyeler $\% 50$ den fazla kuvars ve/veya karbonat içerir ki bunlar daha fazla kırılgan olma eğilimleri ile çatlaklanmaya uygun özelliklerdedir. Caineng vd. (2010)'e göre kırılgan mineral oranı \%40 dan fazla olduğunda etkin bir çatlatma sağlanmaktadır. (Şekil 4). Örneğin, smektitçe zengin şeyller suya karşı duyarlıdır ve farklı hidrolik çatlatma sıvıları ile işlem görmesi gerekebilir. Bileşimsel özelliklerine göre şeyl kaynak kayalarının hidrokarbon türümü de farklı olmaktadır. Örneğin Bassier ve Haynesville şeylleri daha az karbonat içerirken, Barnett şeylleri kuvarsça zengindir. Gömülme ve diyajenez sırasındaki amorf silikat rekristalizasyonu, Barnett şeyllerine göre daha kırılgan bir özellik oluşturur ve bu da hidrolik çatlatmaya daha iyi cevap veren bir özellik olup, daha verimli üretim sağlar (Buller vd., 2010). Devoniyen yaşlı Marcellus formasyonu (Kuzey Appalachian Baseni, USA) Barnett şeyllerine göre daha çok silisçe zengin seviyeler içerir, ayrıca daha yüksek oranda TOC içerir. 


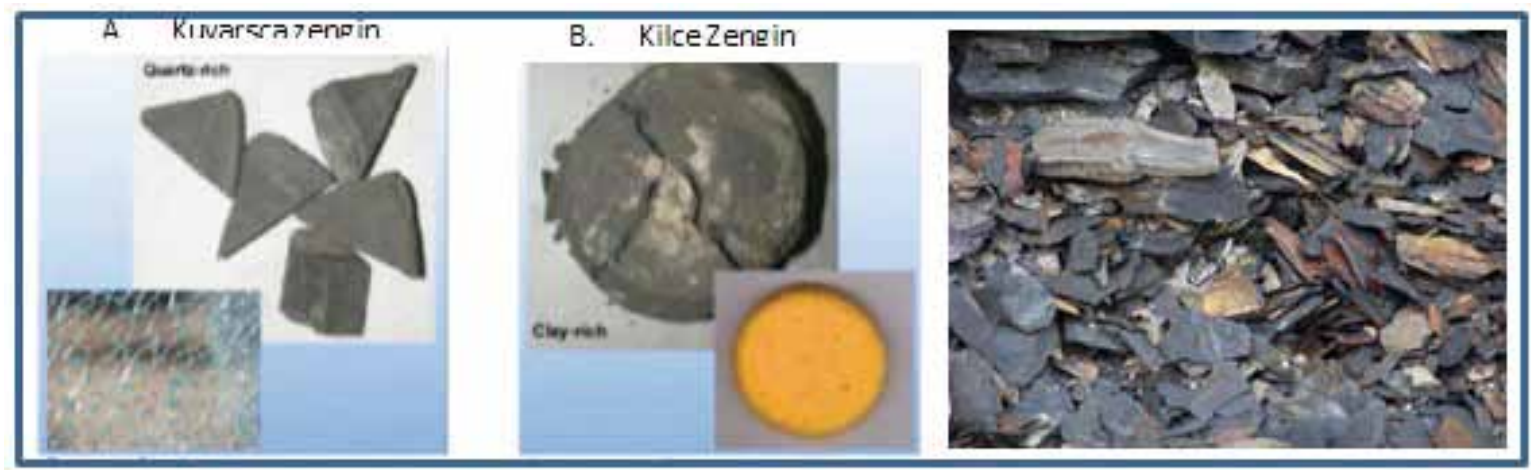

Şekil 4. Amerika'da gaz üretimi yapılan şeyller ve mineralojik özellikleri (A. Barnett Şeyli, B-Kretase Şeyli) (Buller vd., 2010)

Figure 4. Gas productive shales in the United States and their mineralogical properties (A. Barnett Shale, B-Cretaceous Shale) (Buller et al., 2010)

\subsection{Hidrokarbon Oluşumu}

Konvansiyonel veya ankonvansiyonel olarak tanımlansa da üretim yapılan sahalarda aslında aynı süreçler ve unsurlar ile hidrokarbonlar oluşmuştur. Türüm için yeterli organik madde (toplam organik karbon, TOC, \% hacimce), yani organik zenginlik, uygun organik madde (kerojen tipi) ve uygun olgunluk derecesi önemlidir (Tissot ve Welte, 1984). Herhangi bir sedimanter ortamda hidrokarbon oluşumu için öncelikle bir kaynak kayanın olması gereklidir. Bunun karakteristik özellikleri ise çökelim sırasında organik maddece zengin olması ve çökelim sırasında veya sonrasındaki reaksiyonlar ile korunması, değişerek hidrokarbon oluşturmalarına olanak sağlayan bir alan olarak düşünülebilir.

Şeyl gazı potansiyeli sadece belirli özelliklere sahip kayalarda bulunmaktadır. $\mathrm{Bu}$ özellikler;

\section{Toplam Organik Karbon (TOC)} miktarı \%2'den büyük olmalıdır (Amerika'daki şeyl gaz sahalarında bu değer ortalama \% 2 civarındadır). Organik zenginlik, organik maddelerin uygun özelliklerde de olması beklenir (Denizel şeyller tipik olarak Tip II kerojen içerirken (fitoplankton ve denizel ortamlardaki diğer bakteriyal mikroorganizmaların karışımı), gölsel şeyller genellikle Tip I kerojen içerir ve organik madde lipitçe zengin algal kaynaklardan oluşur. Karasal organik maddece zengin seviyeler ile ardalanmalı şeyller ise tipik olarak Tip III kerojen içerir ve köken olan organik madde büyük oranda bitkisel kaynaklıdır. Kayalar, olgunlaşmayı sağlayacak kadar yaşlı olmalı veya kerojenlerin 1sısal olarak parçalıp hidrokarbon türetebilmesi için yeterince derine gömülmüş olmalıdır. Örneğin, vitrinit yansıması (Ro) değeri \% 1.1'in üzerinde olmalıdır ( $\mathrm{Lu} \mathrm{vd.,} \mathrm{2012).} \mathrm{Tip}$ II kerojen için Ro\%1.1, Tip II ve III kerojen için $\% 1.1-1.4$, Tip I kerojen için ise $>\% 0.7$ değeri uygun olabilmektedir (Staff, 2010). Kayaçların bileşiminde kil oranı mümkün olduğunca düşük, kuvars ve kalsit gibi kırılganlığı arttıran minerallerin oranı ise olabildiğince yüksek olmalıdır. Kayaç içerisindeki stres dağılımı mümkün olduğunca çift yönlü olmalıdır. $\mathrm{Bu}$ yönlere dik olarak oluşturulacak yapay çatlaklar kanatlarda gelişmelidir. Kayaç içerisinde gaz oluşumuna bağlı "normalden yüksek basınç (overpressure)" zonu bulunmalıdır. Hedef şeyl seviyesinin kalın olması (en az $100 \mathrm{ft}$ ) ve porozite değerinin de genellikle $>\% 5$ olması verimli şeyl üretim seviyeleri için istenen niteliklerdir (Staff, 
2010). Ancak, Amerika'da gaz üretimi yyapılan şeyllerde (Barnette) porozite \%2-10 arasında değişmektedir.

Bahsedilen bu koşullarda şeyl gaz türümü; birincil organik maddelerin artan gömülme sonucunda gelişen isısal parçalanması, petrolün ikincil termojenik parçalanması ve organik maddelerin biyojenik bozunması ile oluşabilir.

Termojenik Gaz; Organik maddenin veya petrolün 1sısal parçalanması ile, biyojenik gaz ise olgun veya olgunlaşmamış organik maddenin bakteriyal değişimi ile ilişkilidir veya ikincil olarak şeyl gaz rezervine göç ile katılmış da olabilir (Antrim şeyllerinde- Michigan olduğu gibi) (Martini vd., 1998, 2003, 2004; Ridley, 2002). Bunların birlikte bulunduğu rezervuarlarda belirlenmiştir ve "hibrit" sahalar olarak tanımlanmıştır. San Juan Baseni gibi bazı CBM gaz sahalarındaki gazların karışım şeklinde biriktiği ve büyük oranda biyojenik süreçlerle (Scott vd., 1994) oluştuğu belirlenmiştir (Martini vd., 2004). Alberta şeylleri, New Albany şeylleri (Illinois Baseni) ve Willoston Baseninde de rezervuarlarda karışım gazı olduğu belirtilmiştir (Wipf ve Party, 2006).

\subsection{Ankonvansiyonel Rezervuarlarının Özellikleri}

Bir şeyl rezervuarı (gaz şeyli) organik maddece zengin ve ince taneli, doğal gaz içeren bir birimi ifade eder (Bustin, 2006; Bustin vd., 2008). Ancak, şeyl terimi genellikle rezervuarın litolojisini tarif etmek yerine geçirgen olmayan ve içinde doğalgaz bulunduran çamurtaşı gibi birimler içinde kullanılmıştır. Amerika şeyl gaz rezervuarlarındaki incelemeler yalnızca şeyllerde gazın oluşmadığı, çamurtaşlarından silttaşlarına ve ince taneli kumtaşlarına (silisli ve karbonat bileşimli) kadar geniş bir litolojinin bu türüm için etkin olduğunu göstermiştir. Örneğin Eagle Ford formasyonu (Amerika) sadece şeyl ve çamurtaş1 değil, ayrıca fosilli karbonatlı bir marndır (Lash ve Engelder, 2011).

İnce taneli, kilce zengin kayaçlarda kapiler güç yüksek ve permeabilite ise düşüktür. Bu kayaçlarda bulunan hidrokarbonlar matriksten atılmaya uygun değildir. Oluşan hidrokarbonların genellikle gaz olması nedeniyle şeyl kaynak kayaları yüksek boşluk basınçları içerir. Örneğin Haynesville gaz şeyli ve Marcellus şeyli sırasıyla yaklaşık 0.9 ve $0.85 \mathrm{psi} / \mathrm{ft}$ değerlerinde sıvı (fluid) basınç gradyanına sahiptir (Engelder vd., 2014). $\mathrm{Bu}$ veriler değerlendirilerek yüksek basınçların rezervuarlarının daha ekonomik üretim değerlerine yükselmesine yardımcı olmasına çalış1lır (Bryndzia ve Braunsdorf, 2014). Kaynak kaya rezervuarlarının Marcellus şeylinde olduğu gibi herhangi bir tektonik faaliyet nedeniyle kırılıp parçalanması termojenik gazların yüzeye kaçmasına, buna bağlı olarak da basıncın düşmesi, ardından üretim kaybına neden olur (Etiope ve Schoell, 2014).

Kil minerallerinin rekristalizasyonu, çökelim, sıkışma, diyajenez (smektitten illite dönüşüm) nedeniyle organik maddece zengin şeyllerde düşey olarak transvers isotopi izlenir. $\mathrm{Bu}$ sonuçlar hem düşey ve hem de yatay yönde elastik ve mekanik kaya özelliklerinde güçlü anizotropi geliştirir (Lucier vd., 2011). Anizotropik kayaç özellikleri ile yapısal unsurların birlikteliği hidrolik çatlatma plan ve yöntemi için önemli bir kriterdir. Dodecane ve su karışımı gibi yeni yöntemler ile şeyler içinde iki farklı porozite ağının varlığı belirlenmiştir. "Dual porozite ağı" olarak adlandirılan bu porozite sistemi su ve petrolle 1slanmış boşluklar içerir. Farklı boşluk ağları ayrıca nükleer magnetik rezonans teknikleri ile de belirlenebilmektedir (Odusina vd., 2011). 


\section{ANKONVANSIYYONEL ENERJI KAYNAKLARININ DÜNÜ VE BUGÜNÜ}

Şeylli formasyonların yüksek oranda hidrokarbon içerdiği bilgisi yeni bir keşif değildir. Ancak, bu kaya türlerinin kendiliğinden petrol ve doğalgaz akışına izin vermeyecek ölçüde geçirimsiz olması nedeniyle 20 yıl öncesine kadar ekonomik olarak üretim yapılmasının mümkün olmadığ1 düşüncesi yaygındı. İlerleyen dönemlerde ise geçirimliliğin yapay olarak sağlanabileceği fikri ve sayısız deneme ve bunlardan edinilen deneyimler sonucunda edinilen bilgiler doğru yolda olunduğunun da ispatı gibiydi. Hidrolik çatlatmanın geliştirilmesi bu yolu açan bir keşif olarak düşünülebilir. İlk olarak 1950'li yıllarda ABD'nin Ohio Eyaletinde uygulanmış olduğu bilinen hidrolik çatlatma yöntemi günümüzde teknik olarak oldukça gelişmiş ve uygulama yaygınlığını artmıştır.

$$
\text { Jeolojik bilgiler, mühendislik }
$$
uygulamaları ve teknolojinin birlikteliğinin şeyl formasyonlarından ekonomik miktarlarda hidrokarbon elde edilebilecek şekilde bir araya getirilmesi, Texaslı bir petrol mühendisi ve işadamı George Mitchell'in girişimleri sayesinde gerçekleşmiştir. 1981 yılında Texas, Forth Worth havzasında bulunan Barnett şeylinde Mitchell Energy and Development Corp. tarafindan denemelere başlanmış, konvansiyonel gaz üretimi için açılan kuyularda 1981-1990 yılları arasında üretim tekniklerinin optimizasyonu ile, 1999'da ekonomik miktarda doğalgaz üretimi başarılabilmiştir. İlgili Ar-Ge çalışmalarında yaklaşık 6 milyon USD harcanmış, geleneksel petrol endüstrisinin olumsuz beklenti ve tahminlerinin çok üzerinde bir başarı elde edilmiştir (Kennedy, 2010). Bugün ABD doğalgaz üretiminin yaklaşık \%5'i yalnızca Barnett şeylindeki kuyularda gerçekleştirilmektedir. $\mathrm{Bu}$ şeyllerdeki rezervuarın net kalınlığ $50-600 \mathrm{ft}$, porozitesi \%2-8 ve TOC değeri \% 1-14 olup, 1000-13 $000 \mathrm{ft}$ derinliktedir. Bu başarı, çok sayıda yatırımcıyı cesaretlendirmiş ve ABD'nin birçok bölgesinde bilinen şeyl formasyonlarında üretim gerçekleştirilmeye başlanmıştır (Şekil 5).

Dünyada konvansiyonel doğal gazın bilinen rezervlerinin \%75' i Ortadoğu, Rusya, Çin ve Meksika Körfezi civarında iken, ankonvansiyonel oluşumlar tüm dünyada (Şekil 6a), geniş bir yayılım alanı sunmaktadır (US EIA 2013b). Amerika Birleşik Devletleri ve Kanada' da konvansiyonel hidrokarbon üretimi geleneksel olmayan enerji kaynaklarına olan araştırma ve üretim teknikleri açısından yapılan yatırımlar ve bunun sonucunda üretim faaliyetlerinin artmas1 nedeniyle giderek azalmaktadır. Özellikle şeyl gazı bu açıdan yerel kaynakların değerlendirilmesi kapsamında küresel enerji pazarında dengeleri değiştiren faktörlerden biri olmaya başlamıştır ve daha geniş alanlarda yayılım gösterir (Şekil 6b).

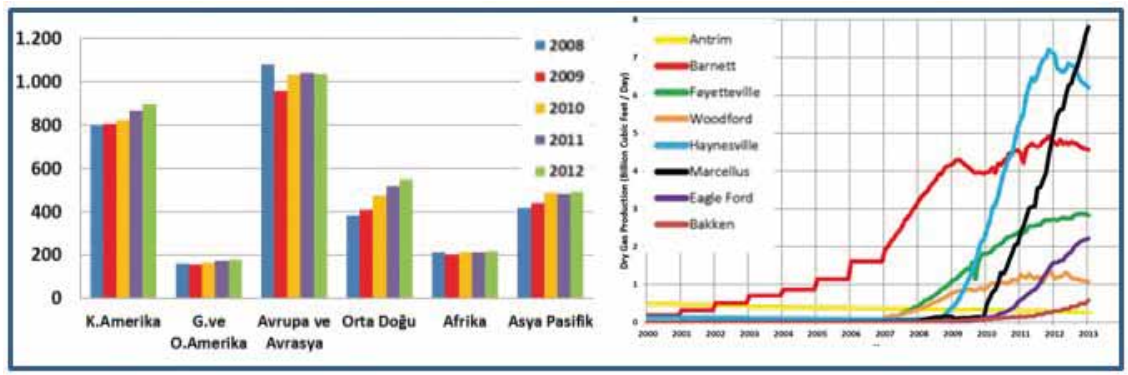

Şekil 5. a) Dünyada doğal gaz üretim miktarı (milyar $\left.\mathrm{m}^{3}\right)$ ve b) Amerika Birleşik Devletlerinde 2000-2013 yılları arasında şeyl gaz üretim değerleri (US EIA, 2013a)

Figure 5. a) The amount of gas production in the World (billion $\left.\mathrm{m}^{3}\right)$ and b) United States shale gas production values between 2000 and 2013 years (US EIA, 2013a) 
$\mathrm{Bu}$ alandaki çalışmalar neticesinde yeni iş kaynaklarının yaratılması, ülkelerin işsizlik sorununa bir miktar çözüm olabilmiştir. Piyasanın canlanmas1, üretilen yeni malzemeler için yeni pazar alanlarının oluşturulması, arazi sahipleri için gelir kaynağı ve yeraltındaki mineral ve yeraltı zenginliklerinden devletin yararlanabilmesi yanısıra büyük ölçüde enerjide bağımsızlık yaratılması açısından önemli sonuçlara sahip olduğu görülür. Diğer taraftan bu enerjiyi savunan ve üretimi sırasındaki etkileri nedeniyle karşı çıkan topluluklar arasında çatışmalar ve muhtemel çevre ve insan sağlığına olan etkileri günümüzde birçok insan tarafindan protesto edilmektedir (Ridley, 2011). kullanılan teknoloji ve yöntemlerin gelişmesi, işletme maliyetlerindeki ve ekonomik koşullardaki değişime göre yapılan hesaplamaların güncellenmesi, mevcut rezervuarların daha iyi etüd edilmesi ve yeni saha keşifleri sonucunda rezervler artmaktadır (US EIA/ARI, 2013b). ABD dışında şeyl gazı arama ve üretim faaliyetlerine yeni yeni başlandığ i için gerçek potansiyel eski çalışmalara dayanan tahminlerin ötesine geçememektedir. Üretimin diğer alanlarda sınırlı olmasına, su sağlanabilirliği, jeolojik özellikler, üretim yapılacak alandaki nüfus yoğunluğu, boru hatlarının durumu ve ulaşılabilirliği ile yasal düzenlemeler ve kamuoyunun ilgisi veya direnci etki eden faktörler olarak sıralanabilir.

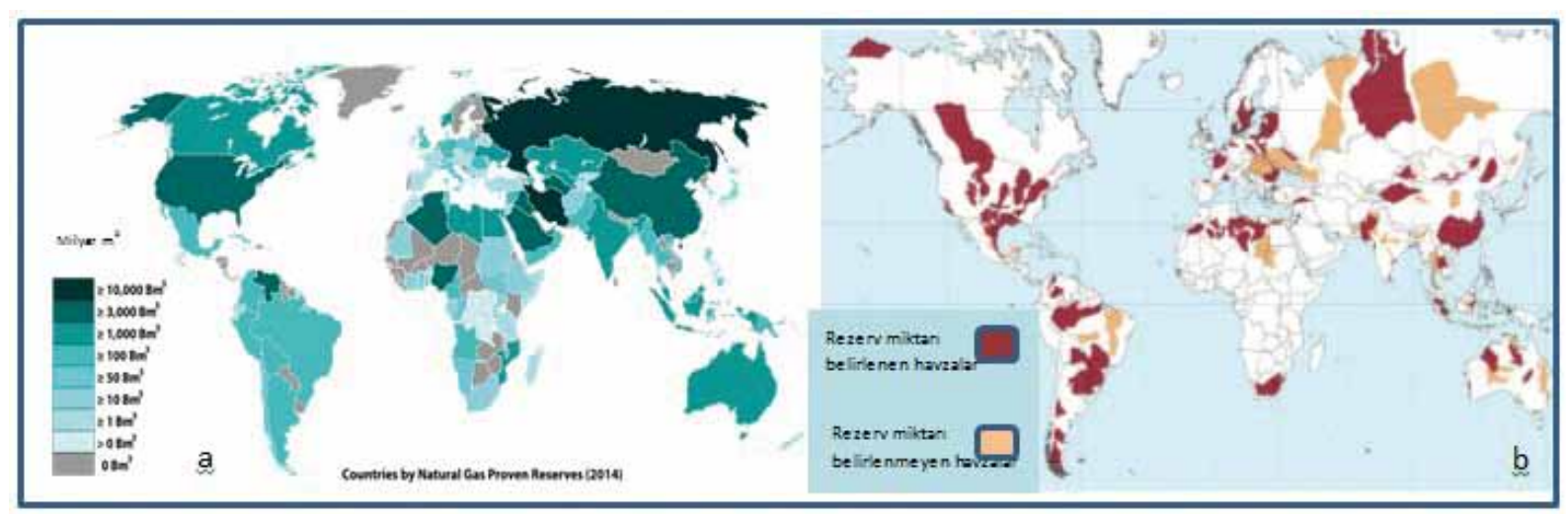

Şekil 6. Dünya'da konvansiyonel (a) ve şeyl gaz rezervlerinin olduğu ülkeler (b) ve rezerv miktarları (Tcf) (US EIA/ARI, 2014)

Figure 6. a) Countries where conventional and shale gas reserves in the world, b) and amount of reserve (Tcf) (US EIA/ARI, 2014)

\section{DÜNYA'DA VE TÜRKİYE'DE}

\section{YAPILAN ARAŞTIRMALAR VE REZERV DEĞERLENDİRMESİ}

2014 y1lı verilerine göre dünyada 41 ülkede geleneksel ve geleneksel olmayan çıkarılabilir doğalgaz rezervleri 790 trilyon $\mathrm{m}^{3}$ seviyesindedir (US EIA, 2013b). Doğal gaz çıkartmak için

\section{1. Ülkelerin Şeyl Gazı Rezervleri ve Üretim Potansiyelleri}

Çin: Çin enerji dünyasında önemli bir yere sahiptir. Genel perspektifle dünyanın en büyük kömür üreticisi ve tüketicisi olup, ayrıca önemli yenilenebilir enerji rezervi ve üretim potansiyeline de sahiptir. Çin'de Sichuan ve Tarim basenleri başta 
olmak üzere 7 büyük havzada (Yangtze Platformu, Jianghan, Greater Subei, Junggar, Songliao) (Şekil 7a) toplam $1115 \mathrm{Tcf}$ rezerv belirlenmiş olup, tek bir ülkede varolan en mükemel şeyl gaz rezervidir (Rezaee ve Rothwell, 2015). en önemli sorun ise genellikle yeterli suyun olmayışıdır.

Amerika Birleşik Devletleri (ABD); ABD şeyl gazı devrimi, başta Teksas, Kuzey Dakota ve Pensilvanya bölgelerinin düz

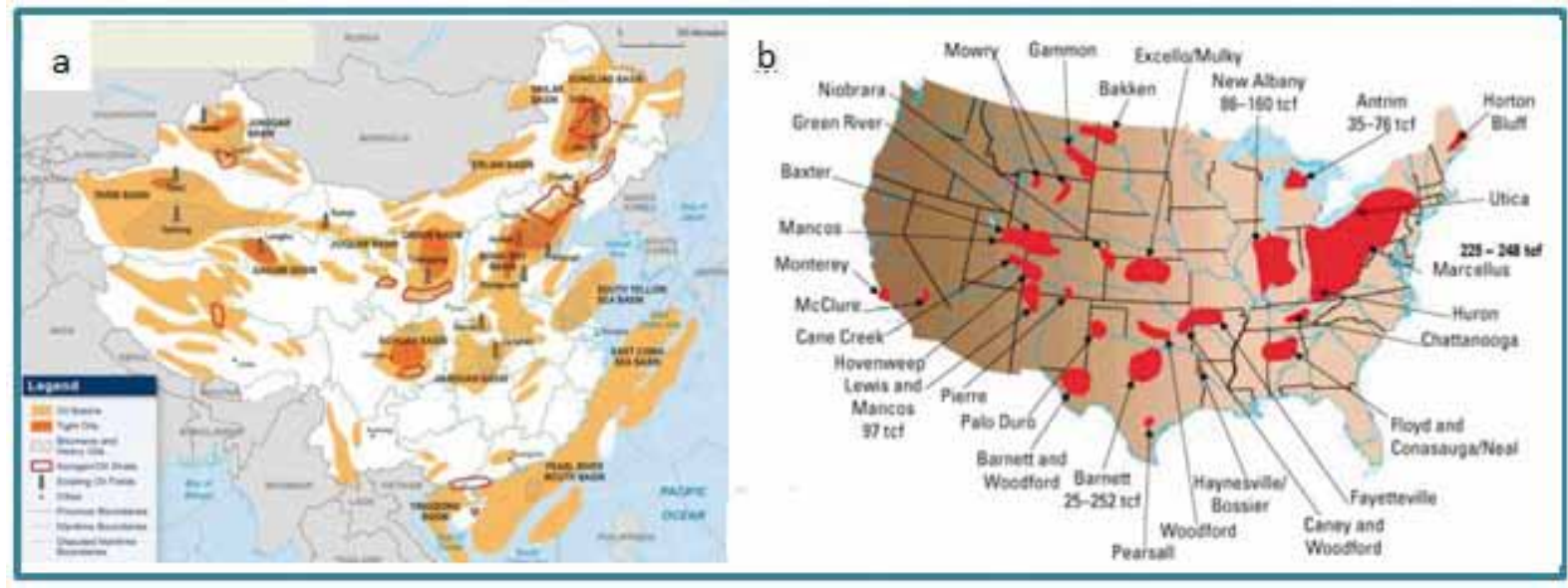

Şekil 7. a) Çin ve b) Amerika'da şeyl gaz potansiyeli bulunan alanlar (US EIA, 2013b)

Figure 7. a) potential shale gas fields found in China and b) America (US EIA, 2013b)

Özellikle Sichuan Baseninde Longmaxi formasyonu 287 Tcf lik rezerv ile en önemli yere sahiptir. Sichuan ve Tarim basenlerinde bulunan 4 önemli şeyl seviyesi, Kambriyen-Silüriyen yaşlı olup, denizel ortamdaki pasif kıta kenarı ortamında çökelmiştir. Kalın şeyl istifleri (200$400 \mathrm{ft}$ ) kuru gaz aşamasındadır (Ro \% 2.0-2.5). Bileşiminde sadece \%2-3 TOC gibi organik zenginliğe, orta derecede kil bileşimine sahiptir ve hedef seviyeler nispeten derinlerdedir (1000014000 ft). Çin'in dağlık Sichuan Havazası'nda coğrafya oldukça engebelidir ve bu durum yatay kuyu sondajını daha zor ve maliyetli hale getirir. Çin'in devlet kontrolündeki petrol-doğal gaz sektörünün esnek olmayan yapısı da kaya gazı gelişimini önleyebilecek bir diğer faktör olarak karşımıza çıkmaktadır (Speight, 2013). Bu enerji kaynağı aslında Çin'deki yerel enerji ihtiyacı için oldukça önemli olmasına rağmen günümüzde şeyl gaz üretimi bulunmamaktadır. $\mathrm{Bu}$ sahalardaki arazilerinde başlamıştır. Önemli şeyl gazı üretimi yapılan alanlarda (Şekil 7b), toplam 1161 Tcf lik rezerve sahiptir (ekonomik ve ekonomik olmayan kaynaklar birlikte ise $4644 \mathrm{Tcf}$ ). Bu alanlardaki şeyller denizel kökenli olup, büyük kısmı foreland basenlerde çökelmiştir ve Devoniyen yaşlıdır (Örn. Appalachian Baseni). Şeyl düzeylerinin bulunduğu derinliğin ülke ortalaması yaklaşık $7500 \mathrm{ft}$ dir ve birçok sahada $3000 \mathrm{ft}$ gibi üretim için daha elverişli seviyeler belirlenmiştir. Organik bileşim genellikle yüksek olup, bazı düzeylerde ortalama \%6-7 TOC görülebilirken, Marcellus şeyllerinde olduğu gibi bazı sahalarda daha da yüksektir (ortalama TOC \%12). Amerika' da ticari anlamda ilk gaz çıkarma sondaj1 1981 yılında denenmekle birlikte, bilinen konvansiyonel doğal gaz yataklarından o dönemin teknolojisi kolaylığı nedeniyle Amerika'da şeyl gaz üretimi 2000'li yıllara kadar beklemede kalmıştır. 1996 yılında yıllık 8,5 milyar metreküp şeyl gaz üretimi 
yapılırken, bu miktar 2006 yılına kadar üç katından fazlasına ulaşarak, 31 milyar metreküp olarak gerçekleşmiştir (Rezaee ve Rothwell, 2015).

Meksika; Çin ve Amerika'dan sonraki en büyük ticari olarak üretilebilir (TRR) şeyl gaz potansiyeline sahip ülkedir (545 Tcf). Toplam 5 basende (Burgos, Sabinas, Tampico, Tuxpan, Vera cruz) ve 6 farkl1 şeyl formasyonunda önemli gaz potansiyeline sahiptir (Şekil 5). Şeyller denizel kökenli olup, Jura ve Kretase dönemlerinin rift ortamlarında oluşmuştur. Şeyl sahalarında birimlerin kalınlığ 1 yaklaşık 200-400 ft olup, düşük kil içeriği, yüksek organik zenginlik (\%35 ortalama TOC) ve yeterli olgunlaşma ile önemli ve dikkat çekici özellikler sunar. Ancak Meksika'daki rezervlerin derinlikleri genellikle 10000-12000 ft arasında değişmekte olup, en verimli kaynak Burgos Basenindeki Eagle Ford şeylleridir (Rezaee ve Rothwell, 2015). Ülkede çok sayıda araştırma faaliyeti olup, üretim için açılan kuyu bulunmamaktadır (US EIA, 2013b).

Güney Amerika'nın Güneyi; Bu alan oldukça geniştir ve özellikle Parano-Chaco Baseni (Paraguay, Brezilya, Uruguay, Şili, Arjantin ve Bolivya) ve Neuquén Baseni (Arjantin) TRR değeri 1431 Tcf' dir. Bu basenlerdeki şeyller denizel kökenli olup, rift ve yay gerisi ortamlarda çökelmiştir. Arjantin'de 4 basen (Neuquén, San Jorge, Avustral, Magallanes), 6 farklı formasyonda toplam 802 Tcf lik rezerv belirlenmiştir. Neuquén Baseni ülkedeki petrol rezervinin yüzde 35 , ini ve doğal gaz rezervinin ise yüzde 47' sini içerir. Parano-Chaco baseni şeylleri nispeten sı ğ derinliklerde (7500 ft), oldukça kalın (1000 $\mathrm{ft}$ ), düşük kil içerikli ve ortalama \%2.5 TOC değerine sahiptir (Rezaee ve Rothwell, 2015). Ancak bunlar olgunluk açısından nispeten düşük değerler sunar (Ro \%0.9). Neuquén Baseni'nde ise 8000-12 $000 \mathrm{ft}$ derinliklerde iki verimli şeyl seviyesi bulunmaktadır. Arjantin'deki Neuquén Baseninde araştırmalar devam etmektedir ve ülkenin en büyük enerji şirketi olan YPF, Mendoza bölgesinde 802 Tcf ankonvansiyonel doğal gaz rezervi belirlemiştir. Arjantin hükümeti "Gas Plus" programı ile yeni keşfedilen sahalara destek vermeye başlamış, 50 den fazla proje bu kapsamda kabul edilmiştir.

Güney Afrika; Ülkenin yaklaşık 2/3 ünü kaplayan Karoo Baseninde 3 adet verimli saha 390 Tcf şeyl gaz rezervi içermekte olup, hepsi de Permiyen yaşlı ve foreland basenlerle ilgilidir. Şeyller nispeten kalın (yaklaşık 100-150 ft), sı̆̆ $(8000 \mathrm{ft})$, düşük kil içerikli, organik maddece oldukça zengin (Whitehill Formasyonunda \%6), olgun-aşırı olgundur. Ancak tek olumsuz özellikleri, birimlerin litolojik özelliklerinin ve bir volkanik (sil) sokulum varlığının kaliteli sismik yansıma kullanım potansiyelini azaltmasıdır (Rezaee ve Rothwell, 2015). Karoo Baseninde önemli bir gaz boru hattı yoktur. Doğal gaz kuzeydeki Mozambik'ten gelmektedir. $\mathrm{Bu}$ alandaki araştırma aktiviteleri çok uluslu şirketler (Shell gibi) tarafından devlet desteği ile yapılmaktadır. 1970 lerden önce açılan bazı kuyular olmakla birlikte 2015 y1lında önemli bir gelişme olmamıştır (Speight, 2013; US EIA, 2015).

Avustralya; Avustralya'da 6 basende (Cooper- Queensland, Maryborough-Perth, Canning, Georgina ve Beetaloo) toplam 11 formasyonda şeyl gaz potansiyeli belirlenmiş olup, TRR değeri yaklaşık 437 Tcf dir. Her bir basen, tip, yaş gibi özellikleri nedeniyle diğer basenlerden farklıdır. Cooper Baseni Permiyen şeylleri gölsel bir ortamda çökelmiş olup, havzadaki diğer şeyller denizeldir.

Cooper Basenindeki şeyller daha sı̆̆ (yaklaşık $8000 \mathrm{ft}$ ), diğer şeyller ise $10000 \mathrm{ft}$ (Perth Baseni) ve $12000 \mathrm{ft}$ (Canning Baseni) arasındaki derinliklerde bulunur. Organik zenginlik düzeyleri (TOC) ortalama \%3.5 civarındadır. Özellikle Cooper Baseninde (Beach 
Petroleum) ve Canning Baseninde (Buru Energy) aktif araştırma faaliyetleri bulunmaktadır. Buna rağmen, Cooper Baseni'nde geleneksel gaz üretimi de devam etmektedir. Canning Baseninde Goldwyer Formasyonu (235 Tcf) ile en büyük potansiyele sahip birimdir (Rezaee ve Rothwell, 2015). Ülkenin birçok eyaletinde su kaynaklarına zarar vereceği endişesi ile bu konuya temkinli yaklaşılmış ve uzun yıllar boyunca önemli bir girişim olmamıştır. New South Wales de bazı sahalarda çalışmalar yapılmaya başlansa da hala ekonomik anlamda önemli üretim için gelişme bulunmamaktadır (CPFIS Shale gas Guidance, 2013; US EIA, 2013).

Kanada; Kanada, toplam 12 basende (Horn River, Cordova, Liard, Deep, Alberta, Doğu ve Batı Şeyl, KB Alberta, Güney Alberta, Williston, Appalachian, Windsor) ve 12 farklı şeyl formasyonunda olmak yaklaşık 573 Tcf şeyl gaz rezervine sahiptir. Bunun büyük kısmı da Western Canadian Basenindeki (WCB) 5 alt basende bulunur. WCB, Rocky Mountain ile ilişkili foreland bir havzadır. Ancak verimli şeyl düzeyleri, denizel ortamın pasif kıta kenarında çökelmiştir. Gaz şeylleri derinlik ve kalınlık bakımından değişiklik sunar, ancak büyük kısmında derinlik yaklaşık $8000 \mathrm{ft}$ ve ortalama olarak kalınlıkları da 200-400 ft arasındadır. Organik zenginlik genellikle yeterlidir (TOC> \%3.5), kil içeriği düşük, 1sısal olgunluk yüksek ve şeyller sıklıkla aşırı basınç etkisinde kalmıştır. Doğu kıyısında özellikle bazı küçük ancak verimli şeyl formasyonları bulunmaktadır. Bunlar arasında Appalachian Baseni en çok bilinen ve verimli olan sahadır (Rezaee ve Rothwell, 2015; Speight, 2013; US EIA, 2013a).

Kuzey Afrika; Afrika kitasında toplam 1361 Tcf lik şeyl gaz rezervi belirlenmiştir. Kuzey Afrika'nın şeyl gaz potansiyeli ise yaklaşı 829 Tcf dir. Bunun büyük bölümü Libya (122 Tcf) ve Cezayir'dedir (707 Tcf). Bu alanda, Ghadames
Baseni (çoğunlukla Cezayir tarafında) ve Sirte Baseni (Libya) önemlidir. Heriki intrakratonik basen de Devoniyen ve Siluriyen'deki denizel şeyl çökelimi ile ilgilidir. İstif kalınlığı 100-200 ft olup, yüksek TOC (\%3-5 ve yerel olarak \%17 den büyük olan kısımlar da bulunmaktadır), aşırı yüksek/normal basınç, ortalama kil içeriği ve yeterli olgunluk verimli gaz sahalarının oluşumu için uygun şartları geliştirmiştir. Ancak tüm bu verimli şeyl düzeyleri 9400 ve $13000 \mathrm{ft}$ arasındaki derinliklerdedir. Ghadames Baseninde uzun süredir araştırma ve incelemeler olmakla birlikte üretim faaliyeti bulunmamaktadır. Bunun dışında, Mısır' da yaklaşık 100 Tcf, Tunus' ta (Ghadames Baseninde) 23 Tcf ve Fas' ta ise 20 Tcf lik rezerv bulunuğu belirtilmiştir (Rezaee ve Rothwell, 2015; US EIA, 2013b).

Avrupa Geneli: Avrupa genelinde, Almanya, Polonya, Romanya, İsveç, Danimarka, İngiltere ve Fransa'da önemli şeyl gaz rezervinin olduğu belirtilmekte olup, toplam rezerv $883 \mathrm{Tcf}$ dir (Rezaee ve Rothwell, 2015). İspanya' daki Cantabrian Baseni Jura yaşlı şeyllerinde ise 8 Tcf lik rezerv belirlenmiştir. Ancak hali hazırda Avrupa'da şeyl gaz üretimi bulunmamaktadır. ExxonMobil Macaristan'da şeyl gaz üretimi için 2009 yılında Mako bölgesinde 5 adet kuyuyu tamamlamıştır. Norveç'te Alum şeylleri de 2011 yılında Shell tarafından incelenmiştir. Ancak, Fransa ve Almanya gibi ülkeler başta olmak üzere bu konu çevreye olan etkileri nedeniyle genellikle arka plana atılan bir durumdadir (US EIA, 2013a, b).

Polonya; Polonya, özellikle diğer Avrupa ülkelerine göre daha fazla şeyl gaz potansiyelinin olması (Şekil 6), çevresel zararları kontrol edebilecek yasal düzenlemeleri yapması yanısıra, iç tüketimde büyük oranda Rus gazına olan bağımlılıklarını azaltmak istemeleri nedeniyle Avrupa'da şeyl gaz çalışmalarının en fazla yapıldığı ülkedir. Polonya'nın hesaplanan TRR potansiyeli 148 Tcf dir. Baltic, Lublin ve Podlasie 
olmak üzere başlıca 3 önemli basendeki şeyller denizel kökenli olup, Siluriyen yaşl1, ya rift veya basenin pasif kıyısı ile ilgilidir. Baltic, Lublin basenlerinde şeyllerin kil oranları ve kalınlıkları (200-300 ft) oldukça yeterlidir. Polodsie Baseninde olduğu gibi iyi organik zenginliğe de sahip (TOC \%6) olmaları nedeniyle önemlidirler. Polodsie Baseninde şeyllerin derinliği $8000 \mathrm{ft}$ civarıdır. Ancak potansiyel üretilebilir kaynak nispeten düşüktür (14 Tcf) ve doğrulanmış potansiyel değer bilinmediği için çok fazla araştırma kuyusu da açılmamıştır. Lublin baseni şeyl seviyesi ortalama derinliktedir fakat düşük organik zenginliğe sahip olup (TOC \%1.5) ortalama olgunluktadır (1slak gaz zonu Ro \%1.35). Baltic Baseni en büyük rezerve sahiptir ve optimum olgunluk ve kuru gaz penceresinde, fakat oldukça derindedir (12 $000 \mathrm{ft}$ ) (Rezaee ve Rothwell, 2015). Baltic ve Lublin Basenlerinde araştırmalar aktif olarak devam etmektedir ve bunlar ayrıca yakınlardaki geleneksel petrol ve gaz sahaları da ilişkilidir. $\mathrm{Bu}$ alanlardaki gazın yerel ihtiyacı 300 yıl karşılayacağı öngörülmüştür (US EIA, 2013a).

Fransa; Fransa'da Paris ve Güney-Doğu Basenlerindeki toplam TRR miktarı 137 Tcf olup, şeyller denizel kökenlidir, düşük-orta kil içeriği, iyi organik içerik (\%2.5-4), iyi olgunluk değeri (Ro \%1.5) ve ortalama kalınlığa sahiptir (100$150 \mathrm{ft}$ ). Ancak bu rezervlerin önemli bir bölümü nispeten derinlerdedir (TRR' nin yüzde 85 lik kesimi 10 000-12 $000 \mathrm{ft}$ arasinda). Teres Noires Şeylleri (Güney Doğu Baseninde) çok sığda (5000 $\mathrm{ft}$ ), düşük kil içerikli, ortalama TOC $\% 3.5$ ye sahiptir. Paris baseni şeylleri de benzer özelliklere sahiptir fakat hedef seviye oldukça derindir (11 $000 \mathrm{ft}$ ). Paris Basenindeki Permiyen-Karbonifer istifinde 127 Tcf lik rezerv bulunmaktadır (Rezaee ve Rothwell, 2015). Fransa, yer altı sularına vereceği kirlilik dolayısıyla, kaya gazı üretimine sıcak bakmayan ülkeler arasındadır ve 2011 yılında hidrolik çatlatma ülkede yasaklanmıştır (US EIA, 2013a).
Rusya; Rusya çok büyük konvansiyonel petrol ve gaz rezervlerine sahip olması nedeniyle şeyl gaz üretimine ihtiyacı olmayan, en büyük tedarikçi ülke durumundadır. TRR değerinin 285 Tcf olduğu tahmin edilmektedir (Rezaee ve Rothwell, 2015).

İskandinavya; İskandinavya Bölgesinde, İsveç ve Danimarka'da Alum Baseninde hesaplanan TRR değeri 10 Tcf olup, Danimarka 32 Tcf rezerve sahiptir. Verimli hedef şeyller denizel kökenli ve Ordovisiyen yaşlı olmakla birlikte sadece bir alandaki şeyller gaz penceresindedir. Yüksek organik zenginlik (ort. TOC \%10), sı ̆ derinlik (3300 ft), düşük kil içeriği, oldukça iyi kalınlık (150 ft) ve gaz penceresindeki olgunluk değeri nedeniyle oldukça iyi bir şeyl gaz rezervinden bahsedilebilir (Rezaee ve Rothwell, 2015). Shell tarafından İsviçre'nin güneyinde bir araştırma programı tamamlanmıştır. Alum şeylleri ile ilgili Danimarka ve Norveç’te sınırlı olarak araştırmalar bulunmaktadır ve araştırma kuyularının açılması planlanmıştır (US EIA, 2013a).

Orta Doğu; Orta Doğu şeyl gaz değeri yaklaşık 138 Tcf olarak belirtilmiştir. Ancak bu alanla ilgili detay çalışma bulunmamaktadır. Bol miktarda geleneksel petrol ve gaz kaynağ 1 olması nedeniyle bu enerji kaynağına ilginin fazla olmadığı açıkça görülmektedir (Rezaee ve Rothwell, 2015).

Hindistan; Cambay, Domodar Valley, Krishna-Godavari ve Cauvery Basenleri olmak üzere 4 farklı alanda toplam TRR değeri 201 Tcf olup, ilk iki basen denizel, son ikisi ise karasal şeyllerdir. Cambay Baseni şeylleri nispeten daha derindedir (13000 ft) ve bunların dişındaki diğer tüm şeyller yüksek kil içeriklidir. Cambay Baseni şeylleri aşırı olgun (Ro \%1.1) ve ortalama organik zenginliğe sahiptir (TOC \%3). Kalın bir istif (500 $\mathrm{ft}$ ) olmas1 nedeniyle de verimli bir seviye olarak tanımlanır (Rezaee ve Rothwell, 2015). Krishna- 
Godavari Baseninde Permiyen-Triyas yaşı şeyllerde 57 Tcf lik rezerv bulunmaktadır (US EIA, 2013a).

Pakistan; Southern Indus Basenindeki Sembar ve Ranikot formasyonlarında toplam 105 Tcf şeyl gaz rezervi bulunmaktadır. Hedef şeyller denizel kökenli olup, foreland basende çökelmiştir. Net kalınlıkları (300-450 ft) ve düşük kil içeriklerine rağmen, ortalama organik zenginliğe sahiptir (TOC \%2) ve hedef zonlar 1slak gaz-kuru gaz penceresindedir (Ro \% 1.151.25) (Rezaee ve Rothwell, 2015).

Kuzey Batı Afrika: Fas ve Cezayir, Bat1 Sahara ve Moritanya bölgelerindeki en önemli ve verimli şeyl gaz sahası olan Tindouf Basenini (50 Tcf şeyl gaz rezervi) paylaşmıştır (Rezaee ve Rothwell, 2015). Tindouf Baseni yeterli organik zenginlik (ortalama TOC \%5), düşük kil seviyesi ve iyi olgunluk düzeyine sahip olmakla birlikte sınırlı yatay yayılımı üretim için sınırlayıcı bir etki olarak dikkat çekmektedir.

Doğu Avrupa; Polonya hariç, Doğu Avrupa'nın şeyl potansiyeli çevresel potansiyel etkileri nedeniyle araştırılmamıştır. Ancak Baltic (Litvanya), Lublin Baseni ve Dnieper-Donets Basenleri (Ukrayna) oldukça önemlidir. Tüm bu şeyller denizel kökenlidir.

a- Baltic Baseni (Litvanya); Hesaplanan TRR değeri 2 Tcf olup Siluriyen yaşlı denizel şeyllerle ilgilidir. Ancak bu şeyller Polonya'daki eşdeğer düzeylerden daha az olgun (Ro \% 1.2) ve daha siğdadır (6700 ft, Polonya'daki $12000 \mathrm{ft}$ ). Bu sahada herhangi bir araştırma bulunmamaktadır

b- Carpathian Foreland Baseni (Ukrayna); $\mathrm{Bu}$ basen Polonya'daki Lublin Baseninin uzantısıdır ve hesaplanan TRR değeri 72 Tcf dir. Şeyl özellikleri benzer olup, L. Siluriyen formasyonunda ortalama TOC yaklaşık \%2.5 dir. Ancak Polonya'daki çalışma ve araştırmalar bu havzada (Ukrayna) yoktur. c- Dnieper-Donets Baseni (Ukrayna);

Ukrayna'da bulunan bu basenin Alt Karbonifer istifinde TRR değeri 76 Tcf dir. Hedef şeyl nispeten kalın (100 ft), derin $(13000 \mathrm{ft})$ ve islak-kuru gaz penceresindedir (Ro \% 1.3). Bu basende de önemli bir şeyl araştırması bulunmaktadır. Doğu Avrupa'nın doğusunda ise West Siberian Central ve West Siberian North Basenlerinde 285 Tcf lik rezerv bulunmaktadır. Ukrayna/Romanya ve Romanya/Bulgaristan sınırlarındaki Moesian Platformundaki L. Siluriyen ve Etropole birimlerinde 47 Tcf rezerv belirlenmiştir (Rezaee ve Rothwell, 2015; US EIA, 2013b).

Almanya ve çevre ülkeler; Kuzey Denizi- German Baseni, Kuzey Almanya, Belçika ve Batı Hollanda boyunca uzanır. $\mathrm{Bu}$ alanda yaklaşık 32 Tcf rezerv hesaplanmış olup, bu 2 farklı verimli şeyl formasyonundadır. Bütün şeyller denizel kökenlidir ve Karbonifer, Jura, Kretase dönemlerindeki rift baseninde çökelmiştir. Şeyl düzeyleri kalındır (75-120 ft) ve orta dereceli kil içeriği, yeterli organik bileşim ve olgunlaşma değeri ile 1slak-kuru gaz penceresindedir (Ro \%1.25-2.5). Wealden şeyli $6500 \mathrm{ft}$, Posidonia ve Namurian şeylleri ise yaklaşık 10 000-12 $000 \mathrm{ft}$ derinliklerdedir. ExxonMobil, Almanya'da önemli şeyl gaz araştırmaları yapmaktadır. Son yıllarda hidrolik çatlatmaya olan tepkiler nedeniyle bu süreç rafa kaldırılmıştır (Bloomberg, 2011 ve 2012). Hollanda ise, West Netherlands Basenindeki birimlerde 26 Tcf lik rezerv belirlenmiştir (US EIA, 2013a).

İngiltere; Şeyl gaz rezervi 26 Tcf olup, bunun 20 Tcf lik kısmı "Kuzey Petrol sistemi/ Norhern UK Carboniferous Shale Region"nde ve 1 Tcf lik kısmı ise "Güney petrol sistemi/ Southern UK Carboniferous Shale Region"ndedir. Herikisi de denizel kökenli şeyller içerir ve Karbonifer ve Jura yaşlı pasif kıta kenarı ile ilgili çökelim sistemleridir. Kuzey petrol sisteminde hedef 
seviye daha sığdadır (4800 ft). Yüksek organik bileşim (\%5.8), uygun kalınlık (150 ft) ve 1slakkuru gaz penceresi zonundadir (ortalama \% 1.4 Ro). Ancak kil oranı yüksektir. Güney petrol sisteminde ise derinlik (13500 ft), organik bileşim ortalama \%2.4 TOC ve Ro \%1.15 olup, Kuzey Petrol sistemi üretim için daha elverişli özelliklere sahiptir (Rezaee ve Rothwell, 2015).

\section{Güney Amerika Kuzeyi; Güney} Amerika kuzeyinde hesaplanan toplam şeyl gaz rezervi 1431 Tcf dir. Bunlar Maracabio Baseni (Venezuela) ve Catatumbo alt basenindedir (Kolombia). 3 adet verimli şeyl seviyesi belirlenmiş olup, bunlar 1slak-kuru gaz oluşum penceresinde, orta kalınlıkta (yaklaşık $200 \mathrm{ft}$ ), orta kil içerikli ve Amerika'daki Eagle Ford şeyl sahaları ile aynı yaştadır. Kolombiya'daki La Luna Formasyonu (Catatumbo Baseninde) yüksek organik madde içeriği (\% 4.5) ve sı̆̆ derinliği $(6600 \mathrm{ft})$ ile daha ümitli görülmüştür. Diğer iki saha ise şeyller düşük organik içerikli (ortalama $\% 1.3)$ ve nispeten daha derindedir (13500 ft). Heriki verimli basen de önemli konvansiyonel gaz sahaları ile ilişkilidir ki bu alanlar zaten jeolojik olarak kompleks özelliklerdedir (Rezaee ve Rothwell, 2015).

Türkiye; Ülkenin hesaplanan TRR potansiyeli 17 Tcf dir. Bunun 11 Tcf lik kısmı Güneydoğu Anadolu (Dadaş Formasyonu), 6 Tcf lik kısmı ise Trakya Baseni'ndedir (Hamitabat Formasyonu). Tüm verimli şeyller denizel kökenlidir, şeyl gaz özellikleri elverişli görünmektedir. Ancak GD Anadolu Baseni daha sığ derinliklerde şeyl içermektedir $(8000 \mathrm{ft})$ ve kalınlıklarda daha uygundur (150 ft). Yüksek organik zenginlik (\%5.5) ve olgunluktadır (Ro \%1.1). Dadaş Formasyonu, SiluriyenDevoniyen yaşlıdır ve organik madde miktarı, olgunluk açısından uygun özelliklere sahiptir. Dadaş Formasyonu Oklohoma'daki Woodford şeyllerine benzetilmiştir. Trakya Baseni’ndeki birimlerden biri çok derinde (14000 ft), diğeri ortalama organik zenginlikte (TOC \%2.5) ve Ro \%1.1 olgunluk seviyesindedir. Türkiye'deki kaya gazı potansiyelinin değerlendirilmesine ilişkin çalışmalar halen TPAO öncülüğünde yürütülmektedir. Bu kapsamda 2010 Transatlantic Petroleum firması ile 2011 yılında ise Shell ile arama ve üretim anlaşmaları yapılmıştır (Bahtiyar, 2012; US EIA, 2013a).

Yukarıda bahsedilen ülkeler dişında Moğolistan (7Tcf), Taylanda (5 Tcf), Endonezya (76 Tcf), Ürdün (7 Tcf) lik rezervlerde belirlenmiştir (US EIA, 2013b).

\section{ARAŞTIRMA, ÜRETIM VE PAZARLAMA}

Şeyl gaz araştırmalarının temelinde, bu birimlerin bulunduğu sahalarının oluşumlarına etki eden jeolojik süreçlerin değerlendirilmesi, şeylli seviyenin makroskobik ve mikroskobik, organik jeokimyasal olarak detaylı incelenmesi yeralır. Özellikle şeyl düzeylerinin çökelim ortam özellikleri, birimin kalınlığ nitelikleri, 1sısal tarihçesi, mineralojik bileşim ve porozite başta olmak üzere petrofiziksel özellikler gibi jeolojik bilgilerin net bir şekilde sağlanması üretim için oldukça önemlidir ve maliyetli bir yatırımda zarar veya kar potansiyelini etkileyen bir unsur olarak dikkat çeker. Etkin ve verimli bir gaz sahası için yüksek organik karbon içeriği (TOC) en az \%2, 1sısal olgunlaşma (Ro\%1.1.1.5) ve birimin yüksek kırılganlığa sahip olmasını sağlayacak mineralojik bileşimi yani düşük kil içeriği oldukça önemlidir. Ancak porozite, stres etkisi, stres tarihçesi de önemli olan diğer faktörlerdendir. Şeyl gazı potansiyeli taşıyan birimlerin yeterli kalınlığa ve yayılıma sahip olduğu alanlarda öncelikle hedef şeyl seviyesi tanımlanır. Deneme kuyuları ile gerekli bilgiler alındıktan sonra "Pilot proje" hazırlanır ve "pilot üretim" denilen öncül üretim yapılır. Kuyudaki 
üretim tamamlandığında ise çevre düzenleme aşamasına geçilerek işlem bitirilir. Bir kuyuda ortalama bir çalışma hızıyla çatlatma yaklaşık 130 gün sürer, burada coğrafi faktörler ve diğer etkenler çalışma hızını oldukça etkiler. $3000 \mathrm{~m}$ lik dik bir kuyuda sondaj maximum 100 gün, çatlatma hazırlık aşaması 1 hafta gerçek çatlatma ise, $20 \mathrm{~m}$ lik bir zonda, 1 gün sürer (Aytuna, 2016, sözlü görüşme). Çatlatma yapıldıktan sonra çatlatma sıvısı kuyu içindeki basınç düşürülerek yüzeye doğru çekilir. $\mathrm{Bu}$ şekilde kuyudan gaz üretimi başlar. Kuyudaki üretim ekonomik anlamını yitirdiğinde gerekli emniyet önlemleri uygulanarak kuyu terkedilir.

Şeyl kaynak kayasının geçirgen olmayan, gözeneksiz yapısı üretim için en büyük engeldir. $\mathrm{Bu}$ nedenle öncelikle hapsettiği gazı serbest birakacak duruma getirilmesi gerekmektedir. Şeyllerden doğalgaz ve petrol elde edilebilmesi için gerekli teknolojik uygulamalar;

- Hidrolik çatlatma: Formasyonlar içine belirli özellikte sıvıların yüksek basınçla pompalanarak çatlaklar oluşturulması, bu sayede hidrokarbonların sızması ve üretim için yüzeye çekilmesine yardımcı olunması işlemlerinin tamamı "Hidrolik Çatlatma-suyla çatlatma" olarak tanımlanır ve bu yöntem 1940'l1 yıllarda Amerika'da keşfedilmiştir.

- Yatay sondaj: Petrol sektörü tarafindan 1980'lerden beri kullanılmaktadır. Oldukça pahalı olması nedeniyle hedef şeyl seviyelerinde oldukça detay mikro-makro ön incelemeler ve modellemeler sonrasinda uygulanabilecek bir yöntemdir (Zhang vd., 2007).

- Sismik arama teknolojileri: Teknolojik gelişmeler paralelinde daha geniş teknik imkânlarla üç boyutlu yeraltı haritaları çıkartılmaya başlanmış olup, incelenecek hedef şeyl alanının detaylı sismik profilleri ile yeraltı ve yüzey koordinasyonu sağlanarak muhtemel operasyon riskleri en aza indirilebilir.

- Ekstraksiyon Yöntemleri: Şeyl gaz ekstraksiyonu, araştırma ve pilot üretim aşaması ile başlar. Hedef alanda 2-3 deneme kuyusu delindikten ve şeyl seviyesi çatlatıldıktan sonra, eğer ekonomik şeyl gazı varsa üretim için planlama aşamasına geçilir. $\mathrm{Bu}$ süreçte daha fazla kuyu ile şeyl seviyesi hakkında detaylı bilgi sağlanarak üretimin en ekonomik nasıl gerçekleşeceğine dair program hazırlanır.

\section{1. Üretim Süreci}

Her şeyl formasyonun kendine has petrolojik özellikleri olduğu için, gaz veya petrol üretimi için uygulanacak yöntem ve teknolojilerin her bir sahada birbirinden farklı olması ve farklı bir üretim planının izlenmesi de kaçınılmazdır. Büyük şeyl sahalarında tek bir şeyl istifinde bile yatay ve düşeyde bu tip heterojenlik nedeniyle üretim sürecinde farklı yöntemlerin uygulanması gerekebilmektedir.

Kaya gazı çıkartmak için kullanılan yöntemler ve teknolojiler, şirketlerin optimizasyon çalışmaları ve bu alanda deneyimin artmasıyla sürekli değişmektedir. Ancak genel hatlarıyla bir kaya gazı çıkartma operasyonunun başlıca aşamaları Şekil 8' de belirtilmektedir.

Hidrolik çatlatma yöntemi; geçirimliliği çok az olan şeyller ve kömür tabakalarında yapılan sondajlarda basınçlı özel bir karışıma sahip su kullanarak çatlaklar oluşturulması ve bu çatlaklar sayesinde gazın sondaj kuyusuna akışının sağlanması esasına dayanmaktadır. Günümüzde hidrolik çatlatma için kullanılan sıvı yaklaşık \%94 su, $\% 5$ kum ve $\% 1$ 'e yakın oranlarda sürtünme azaltıcı, antimikrobiyal ile artık birikmesini önleyici kimyasallar içermektedir. Kullanılan kimyasallar polikrilamid, bromin, metanol, 
naftalin, hidroklorik asit, etilen glikol, bütanol vb. maddelerden oluşur. Şeyl kayaçlarına ve kömür tabakalarına bu amaçla yatay sondaj yapılmaktadır. Böylelikle daha uzun bir mesafede gazı barındıran tabaka içinde çatlakların oluşturulması ve maksimum verimin sağlanması amaçlanmaktadır (King, 2010; Reddy ve Nair, 2012). Yatay olarak şeyl tabakası içine birden fazla sondaj borusu uzatılmaktadır ve yatayda her birinin uzunluğu 2 kilometreye kadar ulaşmaktadır. Sondaj kuyusu içindeki perfore (delikli) boru sayesinde basınçlı olarak kaya tabakasina enjekte edilen suyun içine belirli oranda kum gibi taneli bir malzeme karıştırılmaktadır (Şekil 8). Suyla beraber kum karışımının enjekte edilmesinin gerekçesi, kaya tabakasında çatlakların sonradan kapanmaması ve üretim seviyesinin düşmemesini sağlamaktır. Bu sıvı içindeki bazı kimyasallar ise bu çatlatma işleminin başarılı bir şekilde gerçekleştirilmesine yardımcı olur.

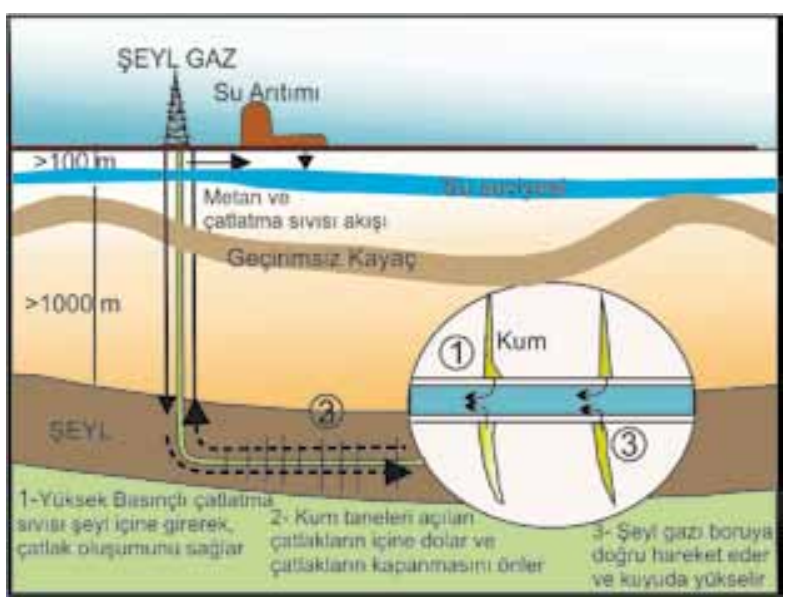

Şekil 8. Şeyl gazı operasyonunun şematik kesiti (www.propublica.org/special/hydraulicfracturing)

Figure 8. Schematic section of shale gas operation (www.propublica.org/special/hydraulicfracturing)

Çevrecilerin çabaları ile şeyl gaz kuyularında geleneksel sulu sistemlere alternatif olarak sondaj ve üretim aşamalarında yeni yöntemler ve ürünler denenmiş ve bunlar "yeşil" yani toksik olmayan eklentiler olarak tanımlanmıştır (Fisher vd. 2014). Yapılan son çalışmalarda, hidrolik çatlatmada kullanılan kimyasal madde içerikli basınçlı su yerine, "sıvılaştırılmış propan" kullanılmasının, hem kirliliği azaltacağı, hem de yüksek orandaki su kullanımını ortadan kaldıracağı düşünülmektedir.

Hidrolik çatlatma sonunda, su yüzeye geri alınmaktadır (Şekil 8). Havuz ve tanklarda depolanıp, gerekli temizleme/arıtma işlemi yapıldıktan sonra yeniden kullanılabilir. $\mathrm{Bu}$ şekilde, geri dönen sıvıların kazanımı operasyonlardaki tatlısu ihtiyacını azaltarak, zaman ve para tasarrufu da sağlamaktadır. Buna ek olarak, günümüzde Pensilvanya'da terkedilen madenlerde drenajı yapılan sular da hidrolik çatlatma için kullanılmaktadır. Bu kazan-kazan anlayışı açısından önemlidir ve özellikle kömür madenciliği için bu ilişki yaygınlaştırılabilmiştir. Ancak terkedilen bu madenlerdeki sularda bulunan yüksek sülfat konsantrasyonu, çatlatma etkinliğini etkilediği için bu konuda araştırma ve geliştirme çalışmalarının detaylı olarak yapılması gerekmektedir.

\section{6. ŞEYL GAZININ EKOLOJİ VE SOSYAL HAYATA ETKILLRI}

Şeyl gaz üretimi birçok ülkede politik- ekonomik ve sosyal alanda değişimlere neden olmuştur ve olmaya devam etmektedir. Bu gelişmeler yanısıra gelecekte nasıl bir manzara ile karşılaşılacağ 1 ve potansiyel çevresel etkileri üzerine devam eden tartışmalar sürmektedir. Çevresel etkiler özellikle ankonvansiyonel gaz üretimi sirasında kamuoyu tarafindan en fazla dikkat çekilen konuyu oluşturmaktadır. Özellikle suyun sağlanabilirliği ve kullanımı, potansiyel yeraltısuyu kirliliği, yüzeye sızan çatlatma sıvıları, hava kirliliği, 
sarsıntı nedeniyle yollarda ve binalarda gelişen çatlaklar ve deformasyonlar ile diğer konular sayılabilir. Bunun dışında ise geri alınan suyun temizlenmesi ile atmosfere salınan sera gazları da diğer sorunlar olarak değerlendirilir (Schrag, 2012; Shine, 2009) (Şekil 9).

\subsection{Doğal olarak oluşan Radyoaktif Materyaller ve iz elementler}

Şeyl gaz üretim çalışmalarında doğal olarak serbestleşen radyoaktif minerallerin (NORMs) hareketliliği rezervuar, sondaj kesintileri ve çatlatma sonucunda geri alınan suya da dikkatleri çekmiştir. Marcellus şeylleri gibi siyah şeyllerde genellikle eser miktarlarda da olsa ${ }^{238} \mathrm{U},{ }^{235} \mathrm{U},{ }^{40} \mathrm{~K}$, ile daha yüksek oranlarda da ${ }^{232} \mathrm{Th}$ bulunmaktadır. Organik maddece zengin şeyllerde $U$ ve Th yanısıra, Mo, V, Cr, Ti ve Mn gibi diğer iz ve eser element zenginleşmeleri de görülebilmektedir. Bunlardan özellikle $\mathrm{Cr}$ ve $\mathrm{V}$ yeraltısularına karışması durumunda önemli sağlık sorunlarına neden olmaktadir. Petrol ve gaz endüstrisi tarafından, üretim ve araştırmalar sırasında çevreye salınan zararlı gazların azaltılması ve çevresel etkilerinin en aza indirilmesi için yüksek

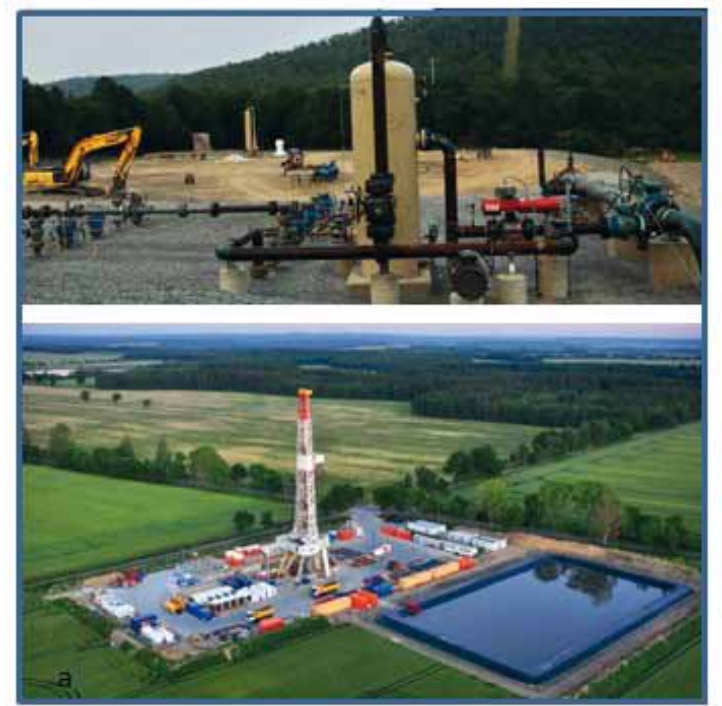

standartlarda önlemler alınmaya çalışmaktadır (Smith, 2011).

\subsection{Yüzey ve Yeraltısu kaynaklarına etkileri}

Yeraltısuyu kirliliği genellikle sığda yapılan "sondaj" veya "çatlatma" işlemleri nedeniyle gelişir ve içme sularına karışan metan ve çatlatmada kullanılan kimyasallar bu kirliliğin en önemli nedenleridir. Hidrolik çatlatma için büyük miktarda su ve kimyasal maddenin yeraltına enjekte edilmesi gerekir ki, suyun miktarı herbir çatlatma için 50 000-100 000 galon (190-380 m³) olup, yatay bir şeyl kuyusu için 1-8 milyon galon (3800-30 $\left.000 \mathrm{~m}^{3}\right)$ su ve binlerce ton veya daha fazla kimyasal maddeye ihtiyaç vardır. Bu kadar suyu hayal edebilmek için ExxonMobil tipik bir yatay şeyl kuyusunda sondaj ve çatlatma için 3-6 olimpik havuz dolusu suya ihtiyaç duyulduğunu belirtmiştir (Olimpik havuz hacmi $2500 \mathrm{~m}^{3}$ veya 660000 US galon) (US EIA, 2013a). Bu rakamlar tatlı su kullanımı için oldukça çarpıcı değerlerdir ve özellikle günlük hayat ve tarımsal faaliyetler, gelecekte temiz su sağlanabilirliği için çok önemlidir.

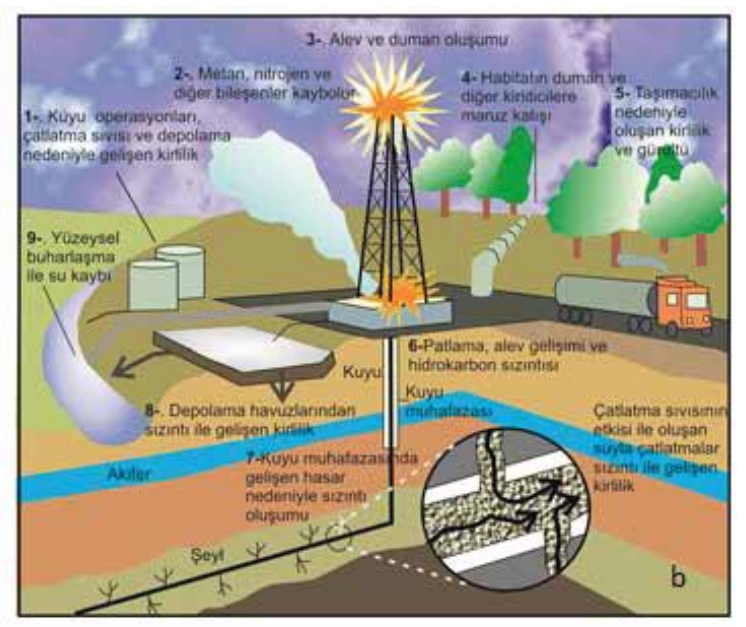

Şekil 9. Şeyl gaz üretimi yapılan bir sahanın genel görünümü (a) ve çevreye olan bazı etkileri (b)

Figure 9. Field overview of performed shale gas production area (a) and some effects of environment (b) 
Hidrolik çatlatma amaciyla kuyulara pompalanan suyun yaklaşı üçte biri yeryüzüne geri dönmektedir. $\mathrm{Bu}$ suyun sımalara karş1 güçlendirilmiş havuzlarda toplanması gerekir (Şekil 9). Havuzlarda biriktirilen su, ya yeniden çatlatma sıvısı olarak kullanılır, ya da arıtılarak kanalizasyona verilir. Terkedilen kuyulara ek olarak, sığ akiferlerdeki doğal gazlar da tehlike yaratan etkilerden biridir. Bu tip kirlilik kaynaklarından daha kötüsü ise arsenik, baryum ve NORM gibi kirleticilerin varlığıdır. İçme suyuna karışan metan özellikle insan ve diğer canlı sağlığ riski de bulunmaktadır (Molofsky vd., 2011; Vidic vd., 2013). Bu kirlilik kaynaklarının ortadan kaldırılması için bazı önlemler alınmaktadır. Örneğin kuyulardan geri alınan suyu, açık havuzlarda biriktirmek yerine, kapalı birikim alanları hazırlanmaktadır. Pensilvanya'daki geri kazanılan suların işlendiği veya temizlendiği tesislerde yapılan araştırmalarda, bu suların aslında tamamen temizlenmesinin mümkün olmadığ1 görülmüştür (Artur ve Cole, 2014). Ayrıca, bu işlemler için oldukça fazla zaman ve para harcanması gerekmektedir ki üretici için bu istenmeyen ekstra bir yük olarak değerlendirilir.

\subsection{Hidrokarbon Çıkışlarının Atmosfere Etkisi}

Doğal gaz kullanımı, dünyada özellikle kömür kullanılan termik santralların atmosfere verdiği partikül ve gazlar ile karşılaştırıldığında çevre için önemli faydalar sağlamaktadır ve birim enerji üretimi için atmosfere salınan gaz miktarının diğer konvansiyonel enerji kaynaklarına oranla daha az olduğu görülmüştür (US EPA, 2012). Son 25 yılda doğal gaz kullanan termik santrallerdeki $\mathrm{CO}_{2}$ emisyonu kömür kullananlara göre $\% 44$ daha azdir.

\section{7. ŞEYL GAZI VE KÜRESEL EKONOMI}

Şeyl gazı araştırmaları diğer fosil enerji kaynaklarına göre yeni bir alandır ve özellikle Amerika dışındaki ülkeler için bilgi ve teknoloji açısından büyük bir birikim ve yatırıma ihtiyaç duyar. Dünyada pek çok ülkede şeyl gaz rezervi olan sahalar belirlenmekle birlikte, her bölgede aynı ekonomik getirinin olması da beklenmemelidir. Örneğin Polonya'daki şeyl gaz üretimi ABD dekinden 3 kat daha pahalıdır. Şeyl gazı üretim maliyetleri sermaye, işletme, nakliye maliyetleri ile vergi ve imtiyaz paylarından oluşmakta olup, ülkeye, coğrafyaya ve operasyonun büyüklüğüne göre çeşitlilik göstermektedir. Sermaye maliyetleri temelde arama ve geliştirme maliyetlerini içermekte ve büyük bölümü ise kuyuların inşaası (sondaj maliyeti) ile ilgilidir. İşletme maliyetleri, üretim faaliyetinin kendisinden kaynaklanan ve değişkenlik sunan maliyetlerdir. Nakliye maliyetleri ise daha çok gazın satılacağı pazarlara olan uzaklıklailgilidir. Dikkatealınması gereken bir diğer veri ise kuyularda kullanılacak su miktarıdır. $\mathrm{Bu}$ suyun tedarik edilmesi ve depolanması da önemli bir harcama kalemi oluşturur. Şeyl gazı kuyularından elde edilmesi beklenen toplam gazın yaklaşık \%25'i üretimin ilk y1lında, \%50'si de ilk 4 yılda üretilmektedir. Hedef bölgeye özgü maliyet bileşenleri ve çıkartılabilecek gaz miktarı birlikte değerlendirildiğinde, operasyonun reel bir getiri sağlaması için piyasada doğalgazın fiyatının ne olması gerektiğine ilişkin bir başabaş noktası belirlenmektedir.

Maliyet için oldukça önemli bir yere sahip olan kuyuların sayısı binlerce olabilmektedir. Şeyl tabakasının derinliğine, yatay sondaj uzunluğuna ve yapısal, su temini gibi faktörlere bağlı olmakla birlikte ABD'de bir şeyl gazı kuyusunun maliyeti 4-10 milyon USD arasında değişmektedir. Kuyu başına elde edilebilen doğalgaz miktarı ise 8 ila 300 milyon $\mathrm{m}^{3}$ arasındadır. Yaklaşık bir 
hesaplamayla 5 milyon USD'ye mal olan ve 30 milyon $\mathrm{m}^{3}$ gaz elde edilebilecek bir kuyunun ekonomik olarak anlamlı olması için piyasada doğalgaz fiyatının 5 USD/MBtu'nun üzerinde olmas1 gerekmektedir (http://ekonomi.isbank. com.tr). Şeyl kuyuları yaklaşık 1000 metre ve daha daha da derinde olduğu ve açılan her 10 kuyudan yalnızca 1 tanesinde gaz elde edildiği istatistiksel olarak ortaya konulduğu düşünülürse alınan riskin büyüklüğü daha kolay anlaş1lır. Bunun dişında şeyl gaz üretimleri günümüzde sadece karada yapılmakta, kuyu maliyetleri ve operasyonel zorluklardan dolayı denizel sahalarda üretim bulunmamaktadır.
-Ankonvansiyonel şeyl gaz teknolojisindeki gelişmeler, şeyl gazının konvansiyonel doğal gaz yerine tercih edilmesine neden olurken, her ülkede şeyl gaz endüstrisinin gelişebilmesi için çevre kanunları ve düzenlemelerinin yapılması gerekecektir.

Günümüzdeki yönelim, doğalgazın dereceli olarak küresel ekonomik pazarda artan oranlarla yer alacağı şeklindedir. Küresel bir etkileşim olması durumunda petroldeki gibi doğalgazda da küresel fiyat belirleyici organizasyonların kurulması ve petrol ve gazın dünyada dengeli fiyat politikası izlemesi sağlanabilecektir (US EIA, 2015). OPEC 2014

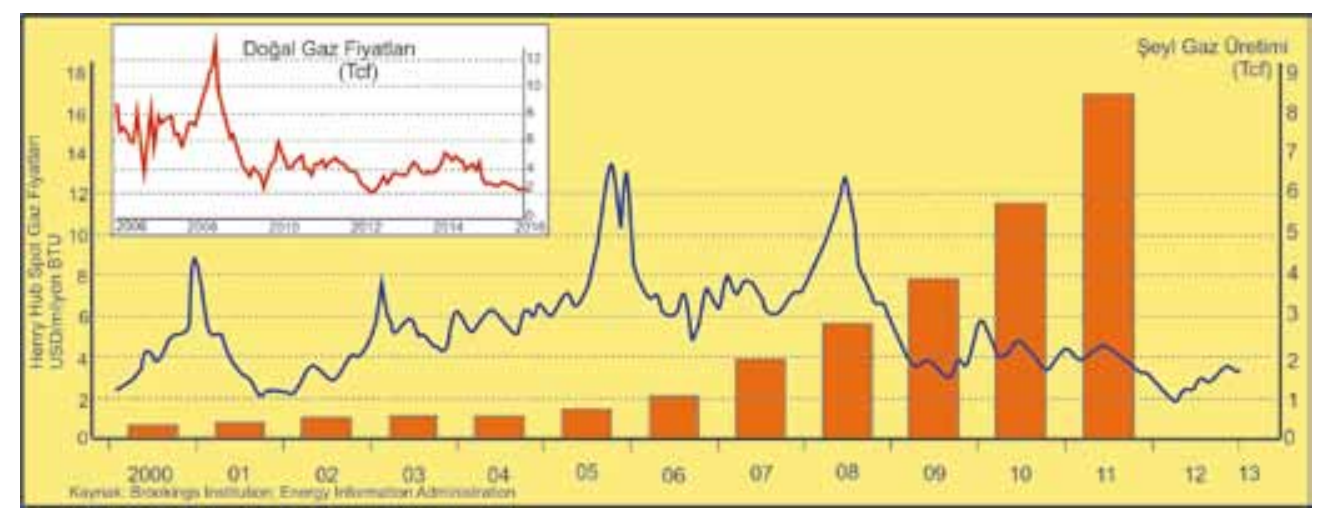

Şekil 10. Doğal gaz ve şeyl gazının ekonomik değerlendirmesi ve tarihsel olarak fiyat değişimleri Figure 10. Economic evaluation of natural gas and shale gas and their historical price changes

Amerika'daki ticari doğal gaz üretim miktarı gittikçe artmakta olup, bu kapsamda şeyl gazının etkisi oldukça önemlidir (Şekil 10). 2040 yılında gaz üretiminin yaklaşık yüzde 50 sinin şeyl gazından üretileceği öngörülmektedir. Ridley (2011) tarafından vurgulandığı gibi, şeyl gazı gelecekte birçok diğer olayı da etkileyebilecektir. Bunlar;

-Şeyl gaz üretiminin artması, potansiyel olarak gaz fiyatlarındaki düşüşü geliştirirken, enerji ihtiyacının artması, gaz ihtiyacının da artması nedeniyle yeni pazarları ve yeni arama ve üretim hedeflerini oluşturabilecektir. toplantısında petrol fiyatlarındaki devam eden düşüşe rağmen üretim kotasını azaltmama kararı almış ve fiyatlardaki düşüş oranı artmıştır. Ancak, 2016 Şubat ayında ise OPEC tarafından üretimi durdurma kararı alınmıştır (www.opec.com). Özellikle Suudi Arabistan'ın üretim kotasının azaltılmasına olan itirazları ABD ve Kanadalı şeyl gaz üreticilerini petrol piyasası dışına atma stratejisi olarak görülmüştür. Başka bir ifadeyle OPEC üyesi bazı ülkeler özellikle kaya gazı üreticileri ile "fiyat savaşı” na girmiştir. 


\section{SONUÇ VE DEĞERLENDİRME}

Günümüzde birçok ülke kendi konvansiyonel olmayan gaz rezervlerini ve bunlardan itibaren yapılacak üretimin, uluslararası doğal gaz piyasaları ve kendi ekonomik dengeleri üzerindeki muhtemel etkisini değerlendirmektedir. Özellikle gaz içeren şeyl tabakalarından hidrolik çatlatma yöntemiyle sağlanan gaz miktarında her bir kuyudan 20-30 yıl üretim yapılabilecek teknolojiye ulaşılmış olması bu parametrenin uzun süreçler ve onlarca değişken etkisiyle değerlendirilmesini zorunlu kılmıştır. Şeyl gaz temini ve kullanım yaygınlığı, fosil yakıtlar enerji sektörü üzerindeki etkisini uzun zamandır göstermektedir. $\mathrm{Bu}$, sadece küresel doğal gaz fiyatları ile sınırlı olmayıp, özellikle Amerika'nın büyük şeyl gazı potansiyeline sahip olması dünyada enerji dengelerini de etkilemiştir. Küresel enerji teminatı, enerji kaynaklarının kullanım oranları, enerji-su-iklim ve tüm bunların küresel enerji sağlanabilirliğine etkisi gün geçtikçe kendini daha fazla hissettirmektedir (US EIA, 2015). Amerika ve Kanada'nın şeyl gazı üretimini artırmasıyla gelişen konvansiyonel doğal gaz üretim-pazarlama dengesi, etkisini gelecek yıllarda da hissettirecek gibi görünmektedir. Günümüzde bile, 20 yıllık süreç içindeki hızlı değişim fosil yakıt dünyasında kuralları koyan Suudi Arabistan, Rusya ve İran'ın yeni enerji politikaları oluşturması yönünde zorlamaktadır. Şeyl gazı potansiyeli konusunda Amerika ve Kanada dişında tüm dünyada yeni rezervler belirleneceğinden küresel enerji denkleminin de önemli ölçüde değişebileceği öngörülmektedir. Ayrıca, Polonya ve İskandinav ülkelerinde bu gazın devreye girmesi ile Rus gazına, Güney Amerika'da ise yeni keşifler ile Bolivya gazına olan ihtiyaç azalacaktır. Amerika ve Kanada'da şeyl gaz üretiminin artması ve Irak'1n doğal üretimi ile dünya pazarlarına girmesi ile Rusya'nın Avrupa'ya karşı enerjiyi bir silah olarak kullanmakta zorlanacağ 1 belirtilmektedir. Şeyl gazın Avrupa'da da enerji fiyatları üzerinde güçlü bir etkisinin olacağı, hâlihazırda uzun süreli sözleşmeler ile Rusya'dan alınan gazın fiyatının önümüzdeki yıllarda düşeceği, Rus ekonomisinin bu durumdan etkileneceği ekonomi çevrelerince dile getirilmektedir. Ülkemiz için değerlendirildiğinde ise Trakya ve Güneydoğu Anadolu Bölgesindeki hedef şeyl formasyonlarının, tabaka derinliği ve kalınlığı, kayaçların mineral bileşimleri bakımından ekonomik üretim için uygun özelliklerde olduğu ifade edilmektedir. Yaygın doğalgaz dağıtım ağı ve yatırımı kolaylaştırıcı yöndeki mevzuatın da şeyl gazı üretimini teşvik edeceği düşünülmektedir.

Şeyl gazın beklenen üretim seviyelerine ulaşmasının Çin gibi ülkelerde özellikle karbon emisyonlarını düşürmek ve enerji güvenirliliğini yükseltmek adına da çok önemli olduğu vurgulanmaktadır. Birçok ülkede hala çevresel etkileri tartışmalar yaratan şeyl gazının gelecekte giderek artan bir yaygınlığa sahip olacağ düşünülmektedir.

Sonuç olarak; uluslararası enerji politikalarında, şeyl gazına bağlı olarak güçlü değişimlerin olacağı açıkça görülmektedir. Gerek doğalgazın diğer fosil yakıtlara oranla daha temiz ve daha verimli bir enerji kaynağı olması, gerekse üretim maliyetlerinin göreli düşüklüğü dikkate alındığında, uygun mevzuatın düzenlenmesi ve sektörün titizlikle denetlenmesi durumunda şeyl gazı üretiminin kayda değer bir çevresel tahribat yaratmayacağ1; aksine kömür ve nükleer gibi daha riskli ve/veya çevreye zararlı yakıt türlerine alternatif yaratarak çevresel açıdan uzun vadede olumlu sonuçlar doğuracağı düşünülmektedir.

\section{KATKI BELIRTME}

Makalenin değerlendirme aşamasındaki katkılarından dolayı Prof. Dr. Mehmet ALTUNSOY (Akdeniz Üniv.) Prof. Dr. Doğan PERİNÇEK'e (ÇOMÜ)ve Dr. Sezgin AYTUNA (AYTUNA Consulting)' ya teşekkür ederim. 


\section{EXTENDED SUMMARY}

It is possible that there is a great changing in the global energy markets, politics and economies in consequence of the rapid development of technology which can be used on the energy sources and to be used as common in the last year over the world. Especially, natural disasters which have been encountered at global scale have drawn attention to the effect of the chemical composition of the atmosphere and compositional changes on humanity and echology in the 20th century. There is an increasing orientation through economic, continuity provided and clean energy sources because of that situation. These sources which are economically seen as a great contribution and are predicted that it will be greater impact potential in the fields of economic, social and politics in the future have been protested on the ground water, surface water and local air quality by millions of people in many countries because of harmful and it has necessitated that these subjects are evaluated in details with the economic benefits.

Today, many countries have assessed production to be made from their own unconventional gas reserves and the possible impact on the international natural gas market and its economic stability. In particular, unconventional resources such as shale gas supply and prevalence of use have affected global natural gas prices and it has also destroyed the balance of power in the world.

Natural gas production from tight shale formations, known as "shale gas", is one of the most rapidly expanding trends in onshore domestic oil and gas exploration and production today. "Shale gas" is natural gas produced from shale formations that typically function as both the reservoir and source rocks for the natural gas. "Gas shales" are organic-rich shale formations that were previously regarded only as source rocks and seals for gas accumulating in the strata near sandstone and carbonate reservoirs of traditional/ conventional onshore gas development. Shale is a sedimentary rock that is predominantly composed of consolidated clay sized particles. Shales are deposited as muds in low-energy environments such as tidal flats and deep water basins where the fine-grained clay particles fall out of suspension in the quiet waters. During the deposition of these very fine-grained sediments, there can also be accumulation of organic matter in the form of algae, plant, and animal derived organic debris. The very fine sheet-like clay mineral grains and laminated layers of sediment result in a rock with permeability that is limited horizontally and extremely limited vertically. This low permeability means that gas trapped in shale cannot move easily within the rock except over geologic expanses of time, i.e., millions of years.

Natural gas is a mixture of light-end, flammable hydrocarbons primarily composed of methane $\left(\mathrm{CH}_{4}\right)$, but also containing lesser percentages of butane, ethane, propane, and other gases. Natural gas is burns cleanly and emits much smaller quantities of potentially harmful emissions than either coal or oil. The widespread use of natural gas-in the industrial, residential, and commercial sectors-is largely due to its versatility. In many countries, such as France, it has been thought that shale gas which has been still argued its enviromental effects will have everincreasing in the future.

Both natural gas is cleaner and more efficient rather than other fossils as a source of energy and when it is considered relatively low production costs and in case the sector carefully monitored, significant production of shale gas may not create any environmental damage arranging of appropriate legislation; unlike it has been thought producing positive results more risky, such as coal 
and nuclear, and / or the environment, creating an alternative to long-term environmentally harmful fuel types. Orientation in our day determines that natural gas will be taken place in economic bazaar with increasing rates as progressively. Instruction of organizations which designates global prices and following a balanced price politics of oil and natural gas will be provided if an interaction comes out in natural gas like oil. So, This paper responds to these needs by describing the importance of shale gas in meeting the future energy needs of the world and providing an overview of modern shale gas development.

\section{DEĞINILEN BELGELER}

Arthur, M.A. ve Cole, D.R., 2014. Unconventional Hydrocarbon Resources: Prospects and Problems. Elements 10:257-264

Bahtiyar, İ., 2012. Türkiye Petrol Jeologları Derneği Basın Açılaması. http://www.haberturk. com/ekonomi/makro-ekonomi/haber/735797turkiyede-40-yil-yetecek-kaya-gazi-var. Erişim Tarihi 03.03.2016

BBC. 2013. North American firms quit shale gas fracking in Poland. BBC News. Available at http://www.bbc.co.uk/news/business-22459629. Accessed May 8, 2013.

Bloomberg. 2011. Shell ends shale gas search in Sweden; invests in China fields. Available at http://www.bloomberg.com/news/2011-07-28/ shell-ends-shale-gas-search-in-swedeninvests-inchina-fields.html. Accessed December 1, 2014.

Bloomberg. 2012. German lawmakers reject ban on shale gas fracking in parliament. Bloomberg News. Available at http://www.bloomberg.com/ news/2012-12-13/german-lawmakersrejectban-on-shale-gas-fracking-in-parliament.html. Accessed December 14, 2012.

Bohacs, K.M., Passey, Q.R., Rudnicki, M., Esch, W.L., 2013. The spectrum of fine-grained reservoits from shale gas tos hale oil/tight liquids: Essential attributes, key controls, practical characterization. International Petroleum Technology Conference, IPTC 16676, 16 pp.

Bryndzia, L.T., ve Braunsdorf, N.R., 2014. From source rock to reservoir: The evolution of selfsourced unconventional resource plays. Elements 14, 271-276.

Buller, D., Hughes, S.N., Market, J., Petre, J.E., Spain, D.R., Odumosu, T., 2010. Petrophysical evaluation for enchancing hydrolic stimulation in horizontal shale gas wells. SPE Annual Tecnical Conf. And Exh., Florence, SPE-132900-MS.

Bustin, R.M., 2006. Geology report: where are the high-potential regions expected to be in Canada and the U.S.? Capturing opportunities in Canadian shale gas. Second Annual Shale Gas Conference, The Canadian Institute, Calgary-Canada.

Bustin, A.M.M., Bustin, R.M., Cui, X., 2008. Importance of fabric on the production of gas shales. SPE Paper No. 114167. Proceedings of the Unconventional Gas Conference, Keystone, Colorado, February 10-12.

Caineng, Z., Dazhong, D., Wang, S., Jianzhong, L., Xinjing, L., Yuman, W., Denghua, L., Keming, C., 2010. Geological characteristics and resource potential of shale gas in China. Petrol Explor Dev; 37 (6): 641-653.

Engelder, T., Cathles, LM, Bryndzia, LT, 2014. The fate of residual treatment water in gas shale. Journal of Unconventional Oil and gas resources 7, 33-48.

CPFI, 2013. Shale gas exploration and production, Key issues and responsible business practices, Guidance note for financiers

Etiope, G., Schoell, M., 2014. Abiotic gas: Atypical, but not rare. Elements 10, 291-296.

Fisher, M.K., Heinze, J.R., Harris, C.D., McDavidson, B.M., Wright, C.A., Dunn, K.P., 2004. Optimizing horizontal completion techniques in the Barnett shale using microseismic fracture mapping. Paper No. SPE 90051. Proceedings of the SPE Annual 
Technical Conference and Exhibition, 26-29 September, Houston, TX.

Kavak, K., 2013. Dünyadaki enerji oyununu değiştiren yeni faktör: konvansiyonel olmayan petrol ve doğal gaz, Enerji Araştırmalar Merkezi Makale No:1

Kennedy, R., 2010. Shale gas challenges/technologies over the asset life cycle. US China Oil and Gas Industry Forum. Baker Hughes.

King, G.E., 2010. Thirty years of gas shale fracturing: what have we learned? Paper No. SPE 133456. Proceedings of the SPE Annual Technical Conference and Exhibition, September, Florence, Italy.

Lakatos, I., ve Szabo, J.L., 2009. Role of conventional and unconventional hydrocarbons in the $21 \mathrm{st}$ century: Comparison of resources, reserves, recovery factors and technologies. Society of Petroleum Engineers; SPE-121775-MS.

Lash, G.G., Engelder, T., 2011. Thickness trends and squence stratigraphy of the Middle Devonian Marcellus Formation, Appalachian Basin: Implications for Acadian foreland basin evolution. AAPG Bull. 95, 61-103.

Lu, S., Huang, W., Chen, F., Li, J., Wang, M., Xue, H., Wang, W., Cai, X. 2012. Classification and evaluation criteria of shale oil and gas resources: Discussion and application. Petrol Explor Dev 39 (2): 268-276.

Lucier, A.M., Hoffmann, R., Bryndzia, L.T., 2011. Evaluation of variable gas saturation on acoustic log data from the Haynesville shale gas play, NW Louisiana, USA. The Leading Edge 30, 300-311.

Martini, A.M., Walter, L.M., Budai, J.M., Ku, T.C.W., Kaiser, C.J., Schoell, M., 1998. Genetic and temporal relations between formation waters and biogenic methane: Upper Devonian Antrim shale, Michigan Basin, USA. Geochim. Cosmochim. Acta 62 (10), 1699-1720.

Martini, A.M., Walter, L.M., Ku, T.C.W., Budai, J.M., McIntosh, J.C., Schoell, M., 2003.
Microbial production and modification of gases in sedimentary basins: a geochemical case study from a Devonian shale gas play, Michigan Basin. Am. Assoc. Pet. Geol. Bull. 87 (8), 1355-1375.

Martini, A.M., Nüsslein, K., Petsch, S.T., 2004. Enhancing microbial gas from unconventional reservoirs: geochemical and microbiological characterization of methane-rich fractured black shales. Final Report. Subcontract No. R-520, GRI05/0023. Research Partnership to Secure Energy for America, Washington, DC.

Molofsky, L.J., Connor, J.A., Farhat, S.K., Wylie, A.S. Jr, Wagner, T., 2011. Methane in Pennsylnvania water wells unrelated to Marcellus shale fracturing. Oil and Gas Journal, pp. 54-67.

Odusina, E.O., Sondergeld, C.H., Rai, C.S., 2011. NMR study of shale wettability. Canadian Unconventional Resources Conf. Alberta-Canada, Soc. Of Petroleum Eng.

Passey, Q.R., Bohacs, K.M., Esch, W.L., Klimentidis, R., Sinha, S., 2010. From oil-prone source rocks to gas-producing shale reservoir-geologic and petrophysical characterization of unconventional shale-gas reservoir. SPE Paper No. 131350. Proceedings of the CPS/SPE International Oil \& Gas Conference and Exhibition, June 8-10, Beijing, China.

Ratner, M., ve Tiemann, M., 2013. An overview of unconventional oil and natural gas: Resources and Federal actions. Congressional Research Service Report R43148

Reddy, T.R., ve Nair, R.R., 2012. Fracture characterization of shale gas reservoir using connectedcluster DFN simulation. Proceedings of the Second International Conference on Drilling Technology 2012 (ICDT-2012) and First National Symposium on Petroleum Science and Engineering 2012 (NSPSE-2012). Sharma, R., Sundaravadivelu, R., Bhattacharyya, S.K., Subramanian, S.P. (Eds.), 6-8 December, pp. 133_136. 
Rezaee, R., ve Rothwell, M., 2015. Gas Shale: Global Significance, distribution, and challenges Fundamentals of Gas Shale Reservoirs, First Edition. Edited by Reza Rezaee. (C) 2015 John Wiley \& Sons, Inc.

Ridley, M., 2011. The shale gas shock. The Global Warming Policy Foundation, Report 2

Schrag, D.P., 2012. Is shale gas good for climate change? Dædalus, J. Am. Acad. Arts Sci. 141 (2), 72-80.

Scott, A.R., Kaiser, W.R., Ayers, W.B., 1994. Thermogenic and secondary biogenic gases, San Juan Basin, Colorado and New Mexico: implications for coalbed gas productivity. Am. Assoc. Pet. Geol. Bull. 78 (8), 1186-1209.

Shine, K.P., 2009. The global warming potential-the need for an interdisciplinary retrial. Clim. Change 96 (4), 467-472.

Smith, A.L., 2011. First correlation of NORM with a specific geologic hypothesis. SPE European Health, Safety and Environmental Conference in oil and gas production, SPE 138136, $17 \mathrm{p}$

Speight, J.G., 2013. Shale gas production Process, Gulf Professional Publ. Elsevier, 162 p.

Staff, 2010. Unconventional gas outlook, the next wave. Volume 1. Draft for participant review. Core Energy Group; Staff. 2025

Tissot, B., ve Welte, D.H., 1984. Petroleum Formation and Occurrence: Springer-Verlag, Berlin.

US EIA 2010. Schematic geology of natural gas resources. Available at http://www.eia.gov/oil gas/natural_gas/special/ ngresources/ngresources. html. Accessed April 19, 2013.

US EPA, 2012. Regulation of Hydraulic Fracturing Under the Safe Drinking Water Act. United States Environmental Protection Agency, Washington, DC.

US EIA, 2013a. Shale gas exploration and production Key issues and responsible business practices, Guidance note for financiers, $34 \mathrm{p}$.
US EIA/ARI, 2013b. Technically Recoverable Shale Oil and Shale Gas Resources: An Assessment of 137 Shale Formations in 41 Countries Outside the United States, $730 \mathrm{p}$.

US EIA/ARI, 2014. Annual Energy Outlook 2014 with projections to 2040, www.eia.gov/forecasts/aeo

US EIA, 2015. The Annual Energy Outlook 2015 (AEO2015), $154 \mathrm{~s}$.

Vidic, R.D., Brantley, S.L., Vandenbossche, J.M., Yoxtheimer, D., Abad, J.D., 2013. Impact of shale gas development on regional water quality. Science 340 .

Yalçın, M.N., 2013. Kaya Gazı (Shale Gas), Doğal Gaz Dergisi, Sayı: 75, (Kasım-Aralık 2012), s.67.

Yergin, D., 1991. Petrol: Para ve güç çatışmasının Epik öyküsü, TC İş Bankası Yay. 332, $742 \mathrm{~s}$.

Wipf, R.A. ve Party, J.M., 2006. Shale Plays-A US Overview. AAPG Energy Minerals Division Southwest Section Annual Meeting.

World Energy Outlook 2015. Yönetici özeti, Ocak 2016 Yayın No: TÜSİAD-T/2016/01/572

Zhang, J., Delshad, M., Sepehrnoori, K., 2007. Development of a framework for optimization of reservoir simulation studies. J. Pet. Sci. Eng. 59, 135 _ 146.

www.ktwop.com

http://www.fractracker.org/2015/08/1-7-million-wells/ http://www.propublica.org/special/hydraulic-fracturing http://ekonomi.isbank.com.tr www.opec.com

\begin{tabular}{|c|c|}
\hline Makale Geliş Tarihi & : 29 Şubat 2016 \\
\hline Kabul Tarihi & : 22 Mart 2016 \\
\hline Received & : 29 February 2016 \\
\hline Accepted & : 22 March 2016 \\
\hline
\end{tabular}

